\section{Pacific Northwest}

National Laboratory

Operated by Battelle for the

U.S. Department of Energy

\title{
Characterizing Building Construction Decision Processes to Enhance DOE Program Design
}
D.J. Hostick
M. Skumanich
A.L. Slavich
M.A. Crawford
L.E. Larson
T.M. Weber
C.J. Hostick

October 2003

Prepared for the U.S. Department of Energy under Contract DE-AC06-76RL01830 


\title{
DISCLAIMER
}

This report was prepared as an account of work sponsored by an agency of the United States Government. Neither the United States Government nor any agency thereof, nor Battelle Memorial Institute, nor any of their employees, makes any warranty, express or implied, or assumes any legal liability or responsibility for the accuracy, completeness, or usefulness of any information, apparatus, product, or process disclosed, or represents that its use would not infringe privately owned rights. Reference herein to any specific commercial product, process, or service by trade name, trademark, manufacturer, or otherwise does not necessarily constitute or imply its endorsement, recommendation, or favoring by the United States Government or any agency thereof, or Battelle Memorial Institute. The views and opinions of authors expressed herein do not necessarily state or reflect those of the United States Government or any agency thereof.

\author{
PACIFIC NORTHWEST NATIONAL LABORATORY \\ operated by \\ BATTELLE \\ for the \\ UNITED STATES DEPARTMENT OF ENERGY \\ under Contract DE-AC06-76RL01830
}

Printed in the United States of America

Available to DOE and DOE contractors from the Office of Scientific and Technical Information,

P.O. Box 62, Oak Ridge, TN 37831-0062;

ph: (865) 576-8401

fax: (865) 576-5728

email: reports@adonis.osti.gov

\author{
Available to the public from the National Technical Information Service, \\ U.S. Department of Commerce, 5285 Port Royal Rd., Springfield, VA 22161 \\ ph: (800) 553-6847 \\ fax: (703) 605-6900 \\ email: orders@ntis.fedworld.gov \\ online ordering: http://www.ntis.gov/ordering.htm
}




\title{
Characterizing Building Construction Decision Processes to Enhance DOE Program Design
}

\author{
DJ Hostick \\ AL Slavich \\ LE Larson \\ CJ Hostick \\ M Skumanich \\ MA Crawford \\ TM Weber
}

October 2003

Prepared for

the U.S. Department of Energy

under Contract DE-AC06-76RL01830

Pacific Northwest National Laboratory

Richland, Washington 99352 


\section{Summary}

There is an established process for the design and construction of buildings. While the particulars will vary greatly from one project to the next, the players (e.g., architects, owners, supplies, builders) and activities (e.g., design, specify, construct) are basically the same, as are the decisions (e.g., which windows where, what type of heating system). The U.S. Department of Energy's (DOE's) Office of Energy Efficiency and Renewable Energy (EERE) tasked Pacific Northwest National Laboratory (PNNL) with the development of a formal framework that could be used to analyze the critical decision path for energy efficient technologies in the construction of buildings. The goal was to demonstrate whether these technologies could be related to decision points in the construction process, the decision makers, and a rudimentary understanding of what helped to form those decisions. The theory to be tested is whether this "Critical Path Analysis" can enhance project planning and design.

A continuous goal of EERE is to increase the effectiveness of its efforts through better targeting of projects. This requires a good understanding of the markets in which EERE technologies and practices, as developed or implemented by those projects, must compete. One significant measure of project success is market adoption of EERE technologies and practices. The goal of this study is to characterize the typical design, construction, and building renovation decision points and decision makers to see if this information could prove useful to DOE Project Managers by helping them understand how market adoption decisions are made.

The approach of this study is to develop a framework characterizing decision points, decision makers, and decision influences in the building industry. As many building design and construction decisions are time-sequenced and constrained by earlier decisions, the framework selected is based on a "critical path" characterization of the design and construction process, capturing the typical sequence of events that drive building technology adoption decisions. This framework is populated with representative data only, as an extensive survey of building industry decision makers was beyond the scope of the study. Sufficient data were collected to determine the usefulness of a building design and construction critical path analysis in supporting DOE project design.

The conclusion of the analysis of the building design, construction, and remodeling process is that a sufficient data set would enable DOE Project Managers to rapidly characterize the building industry decision points, decision makers, and decision influences associated with any given building technology or practice. This information would serve to provide greater insight to project design by showing how a particular DOE project:

- Links or does not link to the decision points in the building industry applicable to the project's building technology categories,

- Targets or does not target the relevant decision makers at those decision points, and

- Addresses or does not address the decision influences faced by the decision makers at each decision point.

If successful, an expanded data set combined with the decision framework documented in this report would serve as a tool to enable DOE Project Managers to confirm that elements required for successful market adoption of a DOE building technology or practice are in place to ensure DOE project success. 


\section{Contents}

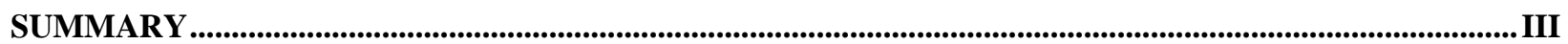

1.0 BUILDING INDUSTRY DECISION PROCESSES AND DOE PROJECT DESIGN .............................1

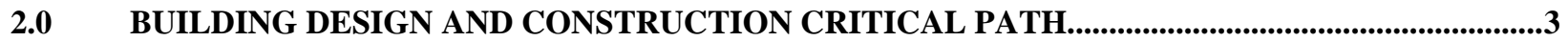

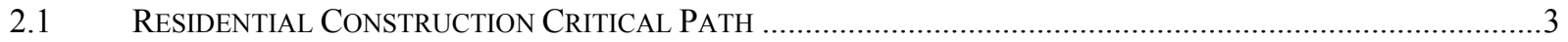

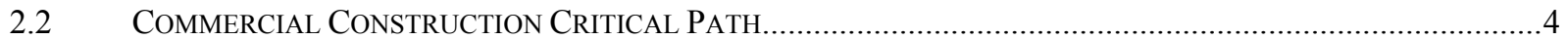

3.0 BUILDING TECHNOLOGY MARKET ADOPTION DECISION MAKERS .....................................5

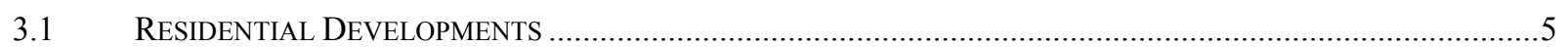

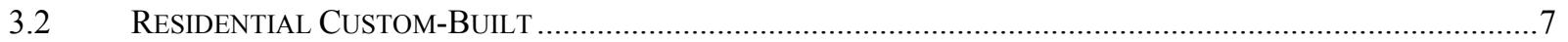

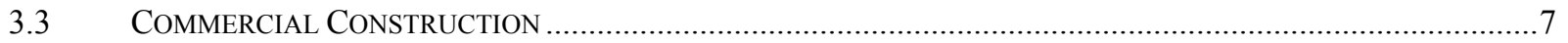

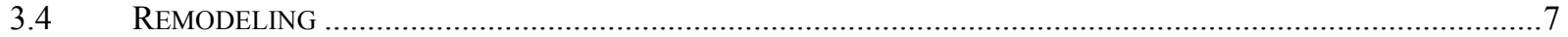

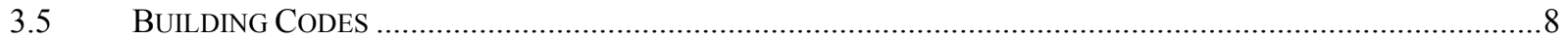

4.0 INFLUENCES AND INFORMATION SOURCES FOR THE DECISION MAKERS ...........................9

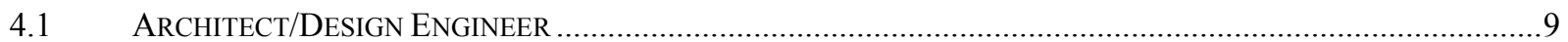

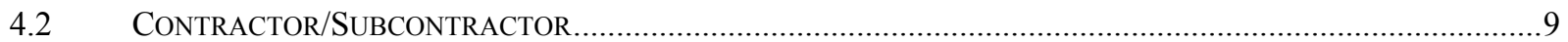

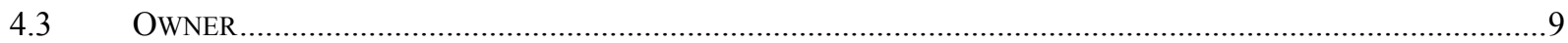

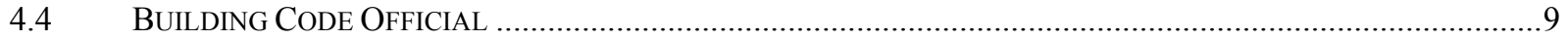

5.0 IMPACTING THE DECISION PROCESS - THE CRITICAL PATH FRAMEWORK .......................11

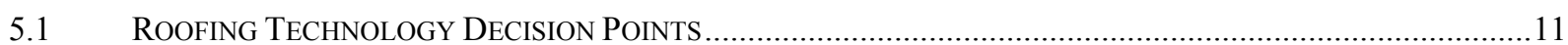

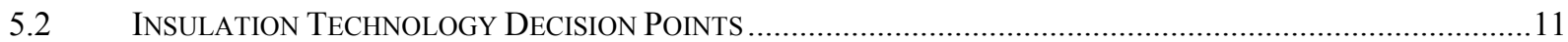

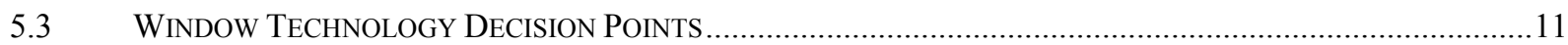

5.4 SPaCe Conditioning/HVAC System TeChnology DeCision PointS ……….....................................12

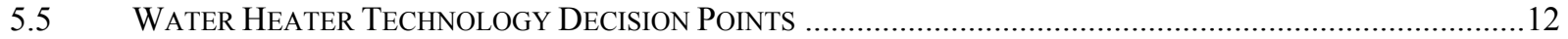

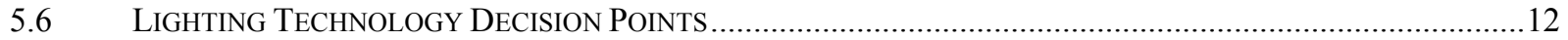

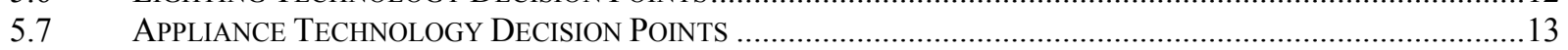

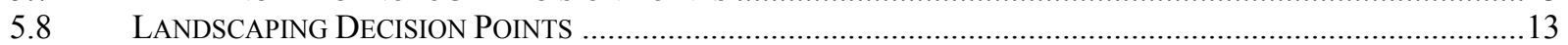

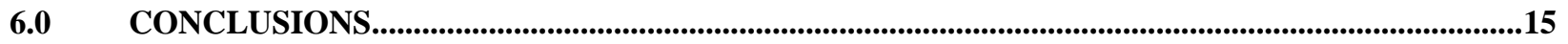

6.1 Contractor-Driven TECHNOLOGY SELECTION DECISIONS..............................................................

6.2 OWNER-DRIVEN TECHNOLOGY SELECTION DECISIONS ……..............................................................

6.3 ARCHITECT/DESIGN TEAM-DRIVEN TECHNOLOGY SELECTION DECISIONS.............................................18

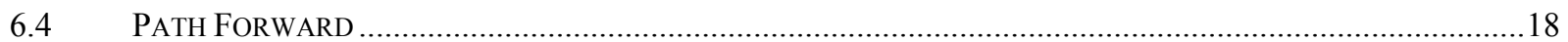

APPENDIX A: TECHNOLOGY ADOPTION DECISIONS AND THE CRITICAL PATH FRAMEWORK

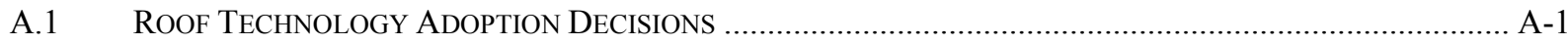

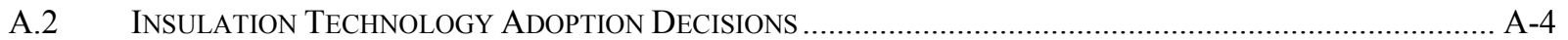

A.3 WINDOW TECHNOLOGY ADOPTION DECISIONS ………................................................................ A-5

A.4 SPACE CONDITION/HVAC SYSTEM TECHNOLOGY AdOPTION DECISIONS ............................................ A-6

A.5 WATER HEATER TECHNOLOGY AdOPTION DeCISIONS ................................................................ A-8

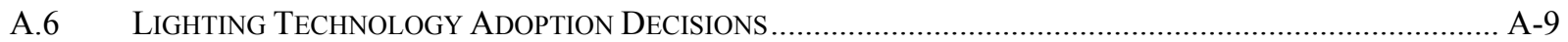

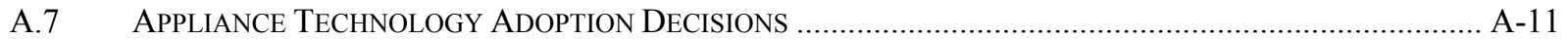

A.8 LANDSCAPING TECHNOLOGY AdOPTION DECISIONS ....................................................................... A-12

APPENDIX B: RESIDENTIAL CONSTRUCTION CRITICAL PATH FRAMEWORK ..................................B-1

APPENDIX C: COMMERCIAL CONSTRUCTION CRITICAL PATH FRAMEWORK............................... C-1

APPENDIX D: CRITICAL PATH ANALYSIS TOOL DOCUMENTATION ….......................................... D-1

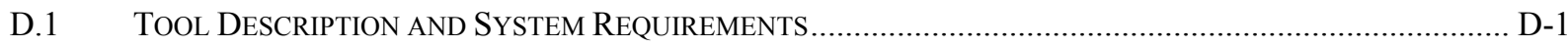

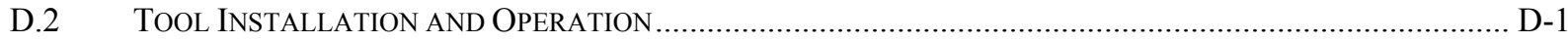




\subsection{Building Industry Decision Processes and DOE Project Design}

In support of the U.S. Department of Energy's (DOE's) Office of Energy Efficiency and Renewable Energy (EERE), the Pacific Northwest National Laboratory (PNNL) investigated whether integrating building design and construction decision processes into project planning can enhance DOE EERE project design.

A continuous goal of EERE is to increase the effectiveness of its efforts through better targeting of projects. This requires a good understanding of the markets in which EERE technologies and practices, as developed or implemented by those projects, must compete. The goal of this study is to identify the key decision makers and explore whether characterizing the typical design, construction, and building renovation decision-making process could provide useful information to DOE Project Managers, enabling them to design projects that link well with the adoption of new technologies in the building marketplace. In short, the goal is to provide DOE Project Managers a view of market adoption obstacles and opportunities early enough in the process to shape project design.

The approach of this study is to develop a framework characterizing decision points, decision makers, and decision influences in the building industry. As many building design and construction decisions are time-sequenced and constrained by earlier decisions, the framework selected is based on a "critical path" characterization of the design and construction process, capturing the typical sequence of events that drive building technology adoption decisions. This framework is populated with representative data only, as an extensive survey of building industry decision makers was beyond the scope of the study. Sufficient data were collected to determine the usefulness of an analysis of the critical path in building design and construction in support of DOE project design. In decreasing levels of effort, the following characterization was completed:

- Identify the key stages in the design and construction process in buildings

- Determine the decisions and decision makers along the path

- Document the factors that influence those decisions

Industry project planning templates were obtained from commercial software products in order to complete the characterization of the key stages in the design and construction process. The resulting critical path of the steps (and approximate duration) of building design and construction activity was documented using Gantt charts. An overview of the critical path characterization of building design and construction activities is contained in Section 2.0.

The determination of decision points and decision makers along the building critical path design and construction process was obtained through interviews with residential and commercial architects, owners, contractors, and building code officials. Contractors included both general contractors and subcontractors. An industry decision process overview is contained in Section 3.0 . 
The documentation of factors influencing decision makers at selected decision points was also obtained through interviews. Although there was not always consensus among the interview respondents, a sufficient "picture" emerged to characterize those factors typically influencing building technology adoption decisions. Decision process influences are summarized in Section 4.0, and the decision points for each technology are summarized in Section 5.0.

Finally, a preliminary packaging of results was completed to illustrate how the assembled information might support DOE Project Managers. This packaging is in the form of a software tool that would enable DOE Project Managers to quickly identify where market adoption decisions are made, who makes the decisions, and what influences the decisions for a particular class of building technology. Four appendixes to this document describe in more detail the decision processes specific to building technology types (Appendix A), the critical path framework for residential buildings (Appendix B) and commercial buildings (Appendix C), and the tool documentation (Appendix D). 


\subsection{Building Design and Construction Critical Path}

As many building design and construction decisions are time-sequenced and constrained by earlier decisions, understanding the overall sequence of events is important to understanding:

- When are building technology and practice decisions made?

- Who makes the decisions?

- What influences the decision makers through the different stages of design and construction?

The framework for characterizing decision points is the "critical path" characterization of the design and construction process, capturing the typical sequence of events that drive building technology adoption decisions. The critical path approach was selected to understand the flow of building related decisions, and how initial activities and decisions constrain subsequent decisions.

Available commercial software products from Primavera ${ }^{\mathrm{TM}}$ and Microsoft Project ${ }^{\mathrm{TM}}$ provide project planning templates for the construction industry. These project planning templates present generic building design and construction steps, the sequence of steps from which the critical path can be determined, and the approximate duration of each activity in Gantt Chart form. Representations of residential and commercial construction were used to identify where technology adoption decisions are made for the following building technology categories:

- Roof

- Insulation

- Windows

- Space Conditioning/HVAC (heating, ventilation, and air conditioning) System

- Water Heater

- Lighting

- Appliances

- Landscaping

The residential and commercial building templates illustrating the steps and associated critical paths of the design and construction process are described in the following sections.

\subsection{Residential Construction Critical Path}

The design and construction steps associated with a single-family house (3,000 square feet with full basement) are contained in Appendix B. There are 88 steps in the design, permitting, and construction process. Figure 2.1 illustrates a simplified view of the residential construction critical path. This figure consolidates the 88 steps into ten steps. The term "General Conditions" captures the design, contracting and permitting steps of the process. All other activities can be classified as construction steps. These steps would be representative of the typical steps associated with a custom-built home. 


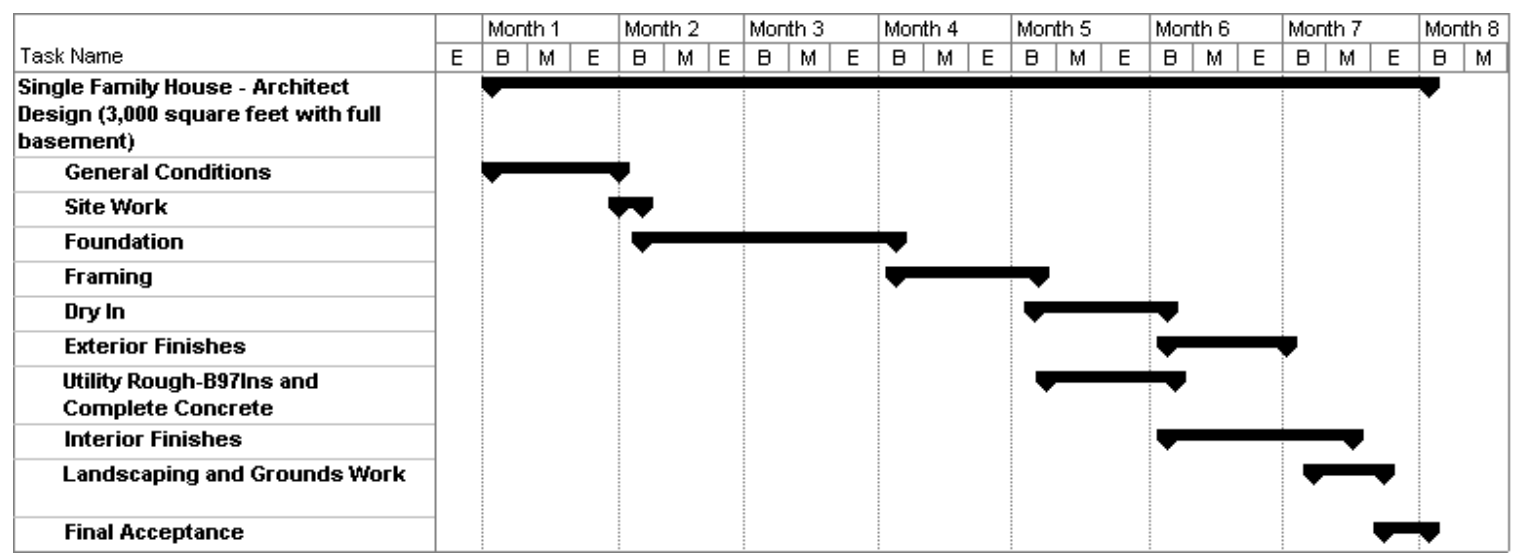

Figure 2.1 Simplified View of the Residential Design and Construction Process

Within Figure 2.1, the Dry In task includes window installation; and Interior Finishes includes insulation, finish plumbing, electrical, and HVAC, and installation of appliances.

\subsection{Commercial Construction Critical Path}

The construction steps associated with a three-story office building (76,000 square feet) are contained in Appendix C. There are 126 steps in the permitting and construction process (design steps are not shown). Figure 2.2 illustrates a simplified view of the commercial construction critical path. This figure consolidates the 126 steps into 18 steps. The term "General Conditions" captures the contracting and permitting steps of the process. All other activities can be classified as construction steps. These steps would be representative of the typical steps associated with a commercial office building.

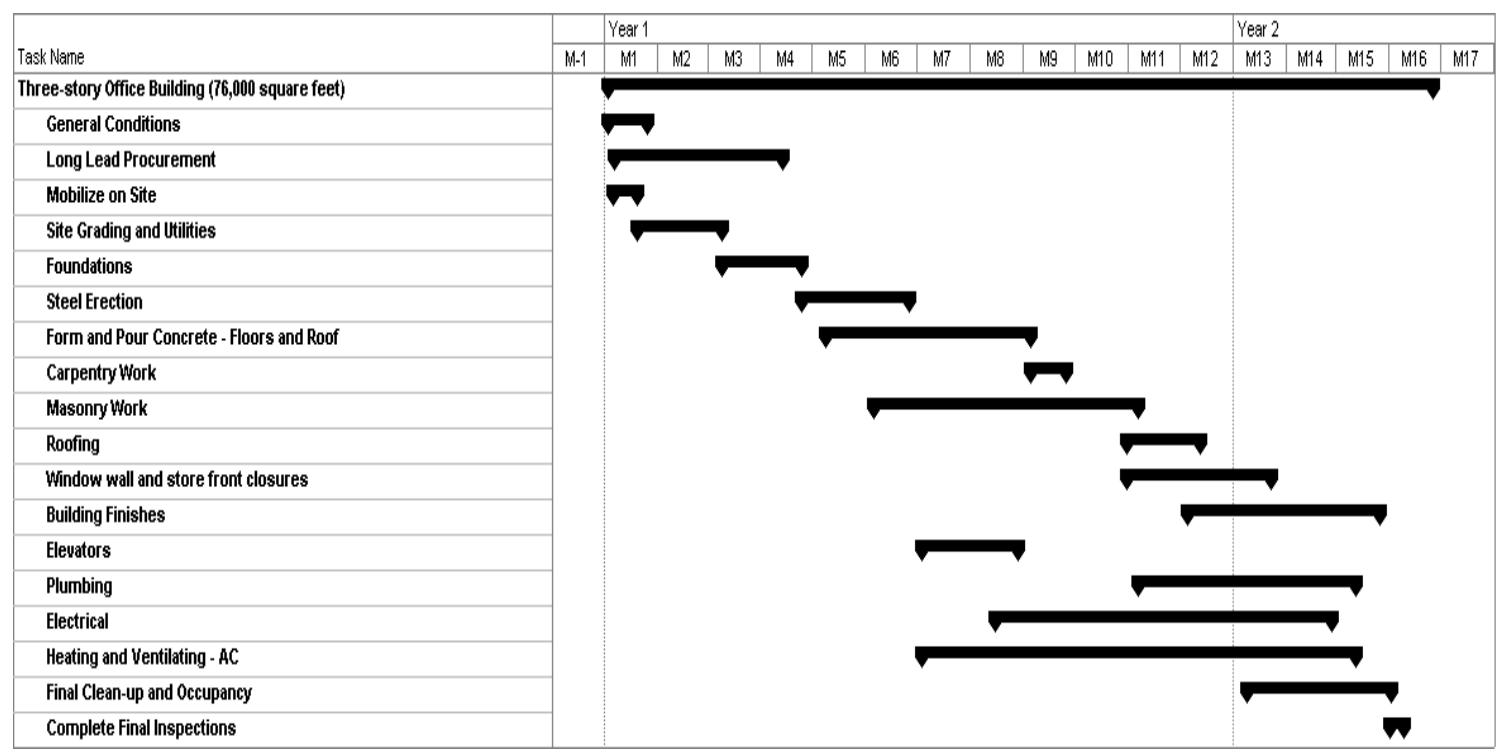

Figure 2.2 Simplified View of the Commercial Design and Construction Process 


\subsection{Building Technology Market Adoption Decision Makers}

A variety of residential and commercial construction decision makers are responsible for building technology adoption decisions. Each of these decision makers can influence building technology adoption decisions at different stages of the design and construction process. Many decisions are sequentially developed by different decision makers. For example, an architect might provide bounds for the type of roofing and materials by specifying the style. In turn, the owner might constrain the selection of roofing material by specifying a budget. Finally, the roofing subcontractor might ultimately select the grade of roofing material working within the given constraints. The list of decision makers include:

- Architect/Design Engineer

- Builder/Contractor

- Owner/Developer

- Renter or Leaser

- Subcontractor

- City and County Officials

- Lender

The design and construction Gantt Charts summarized in Section 2.0 and provided in detail in the appendixes were reviewed by a number of representative decision makers to understand where in the process decisions are made (decision points), who makes the decisions, and what factors influence the decisions. Based on the interviews, the roles and responsibilities for making building technology market adoption decisions varies between residential and commercial construction, and also by the type of construction project (i.e., development versus custom). A summary of the major influences by construction project type, based on interview data, is presented in the following sections. Information regarding decision makers and influences for specific classes of building technology are presented in Section 4.0.

\subsection{Residential Developments}

Developments are investment enterprises that generally have no specific client or homeowner identified prior to construction. Potential customers or clients may be identified in economic terms such as luxury or middle-income. The targeted customer class then dictates the level of sunk costs (e.g., construction material, construction techniques, features, technology, and appliances) that will be invested in the buildings. The overriding consideration is cost per square foot to complete the development. Developments may be completed to a point where the client or homeowner has some options to complete the home. This may consist of carpet selection or finishing touches, but the building envelope, HVAC system, and many appliances may already be specified or installed. Developers usually specify the base level (builder grade) to take advantages of discounts on bulk purchases of such items as appliances and bathroom fixtures across multiple homes. Developers also strive for uniformity of construction design and technique to facilitate standardization of materials, ease of training construction crews, and more straightforward quality control. 
Residential developments are normally initiated by a developer on a tract of land that may have one or more primary construction companies building the dwellings (e.g., single homes, apartments, townhouses). A development may be a combination of these dwelling types or all of one category.

The developer decision maker specifies an overall theme and an anticipated level of pricing for the units. Working within these constraints, an architect lays out the design of the dwellings. Developers work with architects to try to achieve uniform construction methods across the units. This facilitates the ability to use semi-skilled labor to rapidly construct the buildings, and also facilitates quality control, as construction is more standardized and easier to monitor. Also, more standardized designs, and standardized HVAC and appliance packages results in shorter construction times, resulting in lower bids by subcontractors. Shorter construction times are also highly desirable given the appreciable amount of capital the developer has tied up during the construction process.

Once the architect completes the design, the developer solicits bids from contractors and subcontractors. Normally the developer will review examples and/or products from the various subcontractors to determine quality, compliance with the plan and quality for the price. If the developer has a purchase agreement in place with the prospective owner before the subcontractor begins, the prospective owner may alter specifications. These specifications may include such items as the color of appliances, trim, carpet, or mantles. Costs of grades above builder grade are written into the contract. This provides some customizing for the customer, but it is often limited to a pre-agreed list of options specified by the developer in the subcontractor's contract. While limited alterations may be allowed, developers often discourage changes because of the additional communication requirements with subcontractors and suppliers, and because changes can increase the chance for delays to the schedule. Some developers and builders will inflate the cost of the upgrade to discourage changes.

Similar to the developer, subcontractors are interested in standardized products for their supply chain management. Bulk buys of standardized products enable the subcontractor to provide suppliers schedule and quantity requirements that can be used to negotiate discounts as well as help to ensure product availability. Subcontractors give preference to products with which they are familiar and that are easy to install, as this requires the minimum amount of training for their crews and enables them to minimize their time per unit install. Subcontractors are also interested in maintaining a steady flow of work so that their crews are kept busy. These are important considerations, as subcontractors are not paid until installations are complete and the builder or developer accepts their work. The buyer option projects can be less profitable to builders and their subcontractors as greater inventory and/or delays are required to provide the options. Additional complications may develop if the customer changes his/her mind or finds the option unsuitable once installed. From a decision influence standpoint, the customer is selecting options from a specified list, and may have access to samples in a showroom or model dwelling. It is to the advantage of the builder or subcontractor to present the options that provide the greatest profit margin. Profit margin can either be measured directly as a markup on direct costs, or by a somewhat more complex measure that captures the time and skill required to install the option. 


\subsection{Residential Custom-Built}

Compared to residential developments on a per unit basis, custom-built homes are time consuming and involve the eventual occupant at almost every step of the process. Selection of material and appliances may be the recommendation of the architect, builder, or at the request of the owner. There are typically many non-standard construction details and appliances that require close supervision of crews and the integration of numerous subcontractors to meet scheduling requirements. Profit margins can be very high, but such projects tie up personnel and resources for longer periods of time. Customer selection of finishing details and equipment is usually influenced by design centers, the desire for uniqueness, and what is considered fashionable at the time. Energy efficiency decisions and other considerations are usually determined by the homeowner's personal desires and their budget limitations.

\subsection{Commercial Construction}

Within commercial construction, the majority of building technology adoption decisions are made early in the design of the structure. The developer or the client in a custom commercial building, which makes up most of the commercial construction market, will work closely with the architect and the builder/contractor to design and equip the structure. Usually the client has identified specific requirements that the structure has to accommodate. The architect will design to meet those needs and bids will be requested to build to those specifications. Most commercial construction greater than 5,000 square feet will also include an engineer in the design process. The builder/contractor will attempt to meet the requirements of the architectural design while maximizing their profit margin. The builder is also driven by a tendency to select standard products they are familiar with to minimize construction and installation time.

\subsection{Remodeling}

Remodeling projects span the gamut and could be performed by the owner or contracted, and could range from extensive to minor. For residential homes, remodeling is a homeowner initiative and done with a degree of planning over time. Decision influences may be trade shows, exhibitions, publications, utility demand-side management (DSM) program incentives, or personal observations (e.g., store displays and demonstrations). Dealers and distributors may provide some influences on selection of products and materials. Contractors may also influence the decision process by determining what will or will not work in the project or area available. Construction techniques (the technical side of the remodeling effort) are usually left to the architect, if one is used, or the contractor, if it is a smaller scale remodeling effort. Unless specified or advocated by the owner, price and ease of installation will win over all other considerations. Examples include the selection of the insulation R-factor, window type, HVAC system, and quality of siding and roofing materials selected. Most remodeling projects are bid as a job, so the cost of materials together with the difficulty of installation drives building technology adoption decisions. An informed customer may still have considerable influence in the selection of materials and products used in the remodeling project if they are included in the specifications on which the contractor bases their bid. 
Contractor interviews indicate, as expected, that remodeling for long-term use and extended return on investment leads to the selection of higher-end material and products, as opposed to remodeling prior to immediate disposal of the building. Interviews also indicated that once roofing, HVAC and appliance replacement due to age are started in residential developments, contractors can target multiple homes in the development and either obtain and in some cases instigate remodeling efforts.

\subsection{Building Codes}

If building codes exist, the impact of the code on the decision-making process varies depending on how the code is structured and how knowledgeable all parties are about the building codes. Codes officials interpret and establish the minimum "workmanlike" installation. Jurisdictions adopt codes at different rates; some continuously update their codes while others maintain codes that are over ten years old. One other key factor impacting the influence of the building code is whether the code officials actively enforce the codes. 


\subsection{Influences and Information Sources for the Decision Makers}

Building construction decisions are influenced by a number of factors, including a variety of information sources. Awareness of the primary influences and information sources utilized by each group of decision makers can help the DOE Project Manager in designing and marketing a new technology or practice in the most effective manner. More detailed information on the influences to the decision process, by technology type, can be found in Appendix A.

\subsection{Architect/Design Engineer}

Architects are primarily influenced by costs, appearance (e.g., style and aesthetics), and code requirements, although they also consider building use, maintenance, availability, and performance. The architects and design engineers surveyed tend to get their information from industry seminars, trade journals, vendors, and personal networks.

\subsection{Contractor/Subcontractor}

Contractors and subcontractors are primarily influenced by code requirements and first cost. Other factors influencing contractors and subcontractors include schedule, availability (e.g., lead times), installation considerations, familiarity, crew training, equipment performance, and design specifications. The contractors and subcontractors surveyed tend to get their information from industry organizations, trade shows, interactions with suppliers/wholesalers, and publications.

\subsection{Owner}

Owners are primarily influenced by cost and appearance, although durability, familiarity (e.g., brand names), maintenance, and warranty considerations are also taken into consideration. Additionally, in the case of appliances, the features, convenience, and planned usage are also factors in the decision-making process. The owners surveyed tend to get their information from suppliers, contractors and subcontractors, home centers, utility programs, model homes, magazines, and friends or associates.

\subsection{Building Code Official}

Code officials are primarily influenced by the local codes in effect, and their knowledge of those codes. While there are many codes that codes officials are tasked with enforcing, none are more important than those that deal with life, health and safety. Because these types of codes have priority, energy codes enforcement may not be the primary concern of a codes official. The Code Official surveyed stated that the most effective way to inform code officials is through training and seminars. 


\subsection{Impacting the Decision Process - The Critical Path Framework}

Information collected from interviews was used to map the building technology adoption decision process against the design and construction critical path framework presented in Section 2.0. It should be emphasized that the interviews represent a relatively small number of individuals and are not statistically valid. The goal was to demonstrate the Critical Path Framework and the technology adoption decision process for every class of building technology category (e.g., windows, lighting). As such, the Critical Path Framework should not be considered authoritative, but instead informative. More interviews and more detailed data on influences and decision points would be necessary to make this framework operational. More detailed information by building construction and technology type can be found in Appendix A.

\subsection{Roofing Technology Decision Points}

Roof technology selection occurs in the design and early construction (bidding) phases, with architects specifying the overall type by setting a specification (e.g., 30-year shingle, or EPDM membrane thickness), and contractors or subcontractors selecting the actual roofing material (although, in the case of custom-built construction, the owner will also have an influence on these decisions). Changes can be made through the permitting phase, up to the point at which materials have actually been purchased and/or installed.

Interview responses indicate that cost, appearance, and ease of installation influence architects and contractors/subcontractors in roof technology selection.

\subsection{Insulation Technology Decision Points}

Insulation technology selection occurs in the design and early construction (bidding) phases. Building codes specify the minimum R-value allowed in that location. The architect essentially determines the choice of insulation type and material by bounding the space availability, ventilation requirements, and the nature of the construction of the building. Contractors have more limited options in preparing their bid proposals due to these design constraints. While changes can be made through the permitting phase, the type of change may necessitate other revisions to the building design.

Interview responses indicate that costs influence architects and contractors/subcontractors in insulation technology selection.

\subsection{Window Technology Decision Points}

Window technology selection occurs in the design and construction phases. While building codes specify the minimum U-value allowed in that location, the architect is the primary decision 
maker, determining the size, general type, and number of windows, although the owner or developer may also have an influence on these decisions. Contractors will be more limited in their influence on window technology decisions due to the design and code constraints. While changes can be made through the permitting phase, the type of change may necessitate other revisions to the building design, including the evaluation of trade-offs between energy and performance.

Interview responses indicate that cost, performance, and appearance influence architects, contractors/subcontractors, and owners in window technology selection.

\subsection{Space Conditioning/HVAC System Technology Decision Points}

Within residential construction, space conditioning or HVAC system technology selection occurs primarily in the construction phase, although the viability of choices may be bound by design considerations and code requirements. Within commercial construction, the interview respondents indicated that the engineer or architect is primarily responsible for the space conditioning and HVAC technology decisions, again, subject to any code requirements. In both cases, the efficiency and system selected can affect the envelope requirements. While the technology decision can be changed up to the time in which the equipment is actually installed, any components or design features that have already been installed will limit revisions to the decision.

Interview responses indicate that first costs and maintenance requirements influence architects, contractors/subcontractors, and owners in space conditioning/HVAC system technology selection.

\subsection{Water Heater Technology Decision Points}

Water heater technology selection occurs primarily in the construction phase for residential building construction, with contractors or subcontractors making the primary decision (although owners can have an influence on the type of equipment chosen in the case of custom-built). Changes can be made through the permitting phase, up to the point at which materials have actually been purchased and/or installed. For commercial construction, interviewees indicated that commercial building architects constrained the selection of water heater technology options much more so than in the case of residential construction.

Interview responses indicate that cost and performance influence architects and contractors/subcontractors in water heater technology selection.

\subsection{Lighting Technology Decision Points}

Lighting technology selection occurs primarily in the interior finish phase for residential building construction, with contractors or subcontractors making the primary decision (although owners can have an influence on the type of equipment chosen in the case of custom-built). Changes can 
be made up to the point at which materials have actually been installed. For commercial construction, codes are a greater factor in the decision process, as the lighting power density drives the lighting technology and number of fixtures allowed. Depending on the size of the commercial project, an electrical engineer may be involved in the design process. Interviewees indicated that commercial building engineers/architects constrained the selection of lighting technology options much more so than in the case of residential construction because they usually establish a technology specification.

Interview responses indicate that costs, performance, and availability influence engineers/architects, contractors/subcontractors, and owners in lighting technology selection.

\subsection{Appliance Technology Decision Points}

Appliance technology selections can be made early in the process (e.g., bidding within the construction phase), and may be revised through the interior finishing phase. Within residential developments, the developers establish the general price class (e.g., economy or luxury) which bounds the general type of appliances expected in terms of cost, quality, and features. Contractors or subcontractors determine the actual products as part of the bid process. For custom-built residential construction, owners drive the appliance decision process. For commercial construction, interviewees indicated that commercial building architects are primarily responsible for the selection of appliances.

Interview responses indicate that cost, features, and availability influence architects, contractors/subcontractors, and owners in appliance technology selection.

\subsection{Landscaping Decision Points}

Landscaping decisions are usually made in the design and construction phases, and may be revised through the finishing phase. Codes and other requirements can influence the decision process, as they may exist for such items as parking allowances, wetlands or other environmental considerations, and sidewalk strips. Landscape architects, contractors, and owners are primarily responsible for the design decisions.

Interview responses indicate that cost and aesthetics are the primary influences on architects, contractors/subcontractors, and owners in landscape design; however, proven, readily available products are given preference in the design. 


\subsection{Conclusions}

The goal of this project was to determine whether understanding the building technology adoption decision processes along the critical path of design and construction steps could provide useful information to DOE Project Managers, enabling them to design projects that link well with technology adoption in the marketplace. In short, the goal was to provide DOE Project Managers a view of market adoption obstacles and opportunities early enough in the process to shape project design.

This project did not explore the technology decision parameters in more detail, particularly in terms of interactions between both the influences and the technologies. Future areas of research might include the examination of the trade-offs between influences such as ease of installation versus cost margin, and how they further impact the technology decision. Additionally, the prioritization of the technologies themselves was not explored, so future studies might address technology trade-offs, such as whether additional costs might be better-received in window technology decisions versus insulation technology decisions. Another future area of research might also be to further explore why some efficient technologies have not been adopted to the extent expected.

The decision process framework completed in this report is based on limited but representative data. Definitive recommendations regarding how any given DOE project should address market adoption obstacles in their project design will require a larger sample size of industry decision makers. However, some general observations emerge from the information that was collected. These observations provide initial insight regarding market adoption issues that will need to be addressed in order to achieve significant market adoption rates.

Table 6.1 shows a summary of principle decision makers by building component. The following sections describe the typical decisions made by each class of decision maker. 
Table 6.1 Summary of Principle Decision Makers by Building Technology

\begin{tabular}{|c|c|c|c|}
\hline \multirow[b]{2}{*}{ Building Technology } & \multicolumn{3}{|c|}{ Principal Decision Makers } \\
\hline & Contractor/Subcontractor & Owner/Developer & Architect/Designer \\
\hline \multicolumn{4}{|l|}{ Residential Developments } \\
\hline Roof & $\nabla$ & & $\boldsymbol{\nabla}$ \\
\hline Insulation & & & $\boldsymbol{\nabla}$ \\
\hline Windows & $\boldsymbol{\nabla}$ & & $\boldsymbol{\nabla}$ \\
\hline Space Conditioning & $\boldsymbol{\nabla}$ & & \\
\hline Water Heater & $\boldsymbol{\nabla}$ & & \\
\hline Lighting & $\boldsymbol{\nabla}$ & & \\
\hline Appliances & $\boldsymbol{\nabla}$ & $\boldsymbol{\nabla}$ & \\
\hline Landscaping & & $\boldsymbol{\nabla}$ & \\
\hline \multicolumn{4}{|l|}{ Residential Custom } \\
\hline & & & \\
\hline Roof & $\boldsymbol{\nabla}$ & $\boldsymbol{\nabla}$ & \\
\hline Insulation & & & $\boldsymbol{\nabla}$ \\
\hline Windows & $\boldsymbol{\nabla}$ & $\boldsymbol{\nabla}$ & $\boldsymbol{\nabla}$ \\
\hline Space Conditioning & $\boldsymbol{\nabla}$ & $\nabla$ & \\
\hline Water Heater & $\boldsymbol{\nabla}$ & & \\
\hline Lighting & & $\boldsymbol{\nabla}$ & \\
\hline Appliances & & $\boldsymbol{\nabla}$ & \\
\hline Landscaping & & $\boldsymbol{\nabla}$ & \\
\hline \multicolumn{4}{|l|}{ Commercial } \\
\hline & & & \\
\hline Roof & $\boldsymbol{\nabla}$ & & $\boldsymbol{\nabla}$ \\
\hline Insulation & & & $\boldsymbol{\nabla}$ \\
\hline Windows & & & $\nabla$ \\
\hline Space Conditioning & & & $\boldsymbol{\nabla}$ \\
\hline Water Heater & & & $\boldsymbol{\nabla}$ \\
\hline Lighting & & & $\boldsymbol{\nabla}$ \\
\hline Appliances & & & $\boldsymbol{\nabla}$ \\
\hline Landscaping & & $\boldsymbol{\nabla}$ & \\
\hline & & & \\
\hline
\end{tabular}




\subsection{Contractor-Driven Technology Selection Decisions}

Contractors and subcontractors were identified as the principal decision makers for the following building technologies:

- Roofing (Residential Custom and to a lesser extent Commercial)

- Windows (Residential Developments)

- Space Conditioning (Residential Developments)

- Water Heater Technology (Residential Developments and Custom)

- Lighting (Residential Development)

- Appliances (Residential Developments)

Decision influences that determine if a contractor will base a bid on a new technology includes, in addition to anticipated cost margins, the difficulty of installation with semi-skilled labor (cost risk), the availability of products as to avoid schedule disruptions (timing risk), and the uncertainty associated with being the first to try a new technology (performance risk), as contractors are concerned about the potential for call-backs if a technology does not perform as marketed. By addressing these issues in DOE project design, plus communicating that new products are proven and in compliance with codes, would address many of the product adoption obstacles raised by contractors. Not addressing these issues would result in poor market adoption rates where the contractor is the decision maker, even if the new technologies offer excellent cost/performance value to the customer. In order to communicate information on new technologies, DOE needs to mirror the current channels of product information to contractors, which is largely vendor-based.

\subsection{Owner-Driven Technology Selection Decisions}

Owners were identified as the principal decision makers for the majority of custom or remodeling efforts, plus the following new construction categories:

- Roofing (Residential Custom)

- Windows (Residential Custom)

- Lighting (Residential Custom)

- Appliances (Residential Custom)

- Landscaping (Residential Developments and Custom and Commercial)

Communicating the life-cycle value of the building technology has a greater influence on the decision process when the owner is the decision maker. Most decisions are based on aesthetics, costs and features (particularly in the case of appliances). Energy efficient products that do attempt to address all criteria will be met with more market acceptance. The channels used to communicate consumer building-related goods are the same channels (e.g., magazines, model homes, friend/associates) for communicating new building technologies to owner decision makers. 


\subsection{Architect/Design Team-Driven Technology Selection Decisions}

Architects and supporting design team consultants (e.g., electrical engineers) were identified as the principal decision makers for the following building technologies:

- Roofing (Commercial)

- Insulation (Residential Developments and Custom and Commercial)

- Windows (Residential Development and Commercial)

- Space Conditioning/HVAC (Commercial)

- Water Heater Technology (Commercial)

- Lighting (Commercial)

- Appliances (Commercial)

Decision influences include familiarity with products, confidence that the products are proven and meet codes, aesthetics, cost and value. First costs were the overriding decision influence. Some of the decisions (e.g., insulation) were made indirectly, in that space considerations and building design constrained the types of products eligible for the application. DOE project design elements that address the first cost market adoption barrier directly (lower cost products) or indirectly (reduced heat load from energy efficient lighting reducing the space conditioning equipment size), combined with demonstrating that the products are proven and meet code requirements, offers the greatest potential to enhance market adoption. In terms of communication channels for communicating new products, both design tools and professional publications were identified as existing sources of input for making design decisions. Trade and professional associations and conferences or trade shows are also a source of input.

\subsection{Path Forward}

The building technology decision process mapped to the building design and construction critical path framework can provide DOE Projects with insight to potential market barriers as part of project design. The information collected to date, while informative, lacks the rigor that could be obtained with a larger data set. More importantly, while a broad range of building decisions makers were targeted to explore the concepts presented in this report, a more focused targeting of designers and contractors specific to each building technology area could produce more detailed information regarding what is required for a product to be successful in the building industry. This detailed information, based on the samples collected to date, could serve to produce "market success checklists" that could be used to guide and monitor DOE EERE project efforts.

Given the complexity and range of building design and construction activity, decision makers, and decision influences, navigating through a richer data set will be more challenging as the information base is expanded. A prototype of a computer tool to navigate through an expanded information set has been completed and is distributed as part of this report. An overview of the tool is provided in Appendix D. 


\section{Appendix A: Technology Adoption Decisions and the Critical Path Framework}

Information collected from interviews was used to map the building technology adoption decision process against the design and construction critical path framework presented in Section 2.0. It should be emphasized that the interviews completed represent a relatively small number of individuals in one geographic area. The intent was to interview several individuals representing each type of decision maker to understand where technology adoption decisions are made, who makes the decisions, and what influences the decision process. The goal was to see if this process could create a standard framework for understanding residential and commercial design and construction practices that could be used as an aid in DOE project design. More specifically, the goal was to understand the technology adoption decision process for every class of building technology category (e.g., windows, lighting) to enable project managers in those areas to understand the market adoption challenges and opportunities faced by their projects.

If successful, this information could be used to shape and adapt technology project development efforts to ensure that not only technology performance issues are addressed, but all issues that will ultimately be required for the technology to be successful in the marketplace. For example, the interviews indicate that decision makers consider issues such as skill level and timing of installation in technology selection. The interviews also sought to determine what motivates the different classes of decision makers and how decision makers become aware and eventually advocate the use of new building materials, practices, and equipment. This information could aid DOE Project Managers by serving as a guide for review if technology deployment strategies are synchronized with the realities of the construction industry. If successful, this characterization could address such questions as how to best influence roofing subcontractors, for example, to adopt new roofing materials as part of their bid package.

The following sections capture an initial view of the technology adoption decision process by technology category, mapped against the design and construction critical path. Where responses varied among interviewees, responses from those interviewees with the most experience base were given preference.

\section{A.1 Roof Technology Adoption Decisions}

\section{Residential Developments}

The decision points where roof technology adoption decisions are made for residential developments are shown on the simplified critical path chart of construction activities in Figure A.1. 


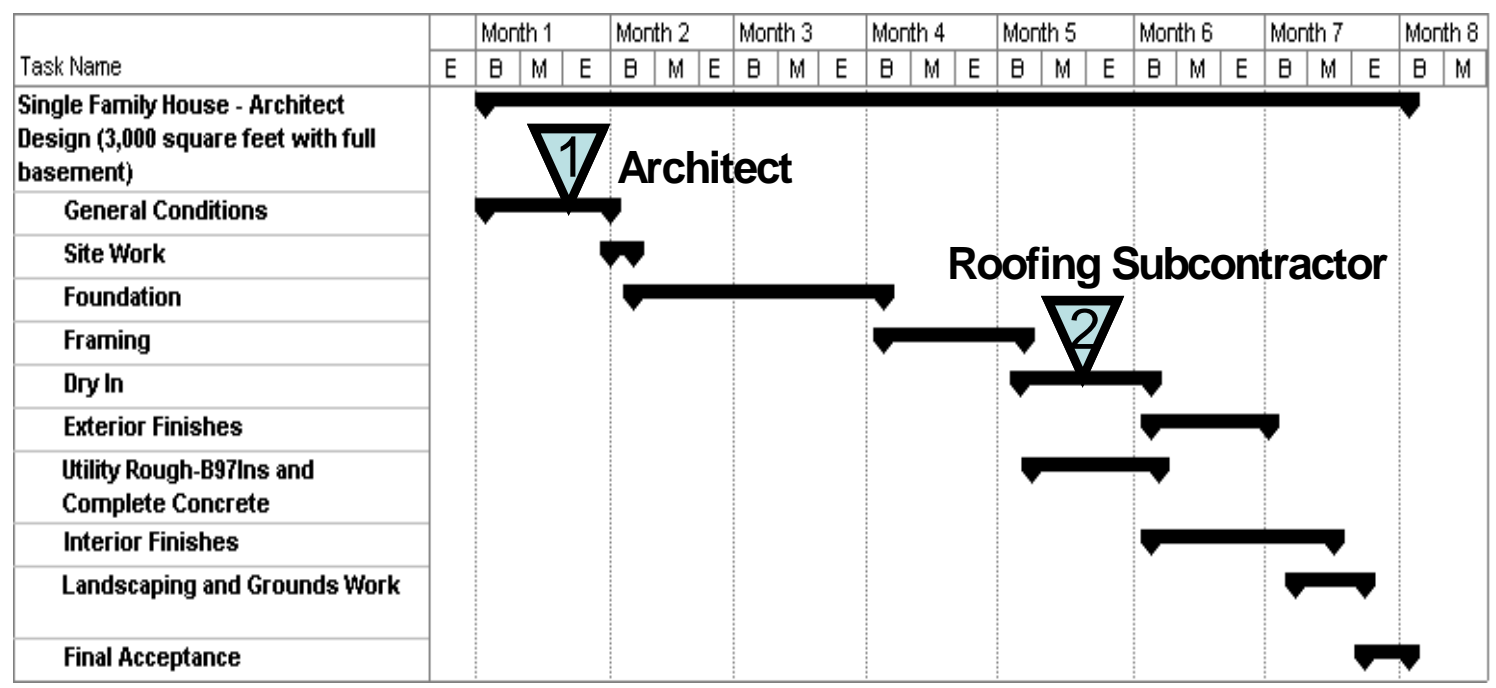

Figure A.1 Residential Development Roofing Technology Decision Points

The roofing technology decision process for residential developments is very similar to the twostage decision process found in commercial construction. The architect or designer often selects the overall type based on cost and appearance, and the roofing subcontractor, as part of their bid process, selects the actual roofing material. Roofing contractors, influenced by crew training and installation considerations, tend to select materials they are familiar with as well as materials that provide them the greatest cost advantage.

\section{Residential Custom Construction}

As expected, owners have much greater influence in making roofing type and material selections in residential custom construction. Cost and appearance still are the dominant decision influences. However, owners tend to be more interested in the life-cycle costs of their roofing decisions as compared to residential developments. Durability and warrantee considerations are part of this decision process.

The decision points where roof technology adoption decisions are made for residential custom construction are shown on the simplified critical path chart of construction activities in Figure A. 2 . 


\begin{tabular}{|c|c|c|c|c|c|c|c|c|c|c|c|c|c|c|c|c|c|c|c|c|c|}
\hline \multirow[b]{2}{*}{ Task Name } & \multicolumn{4}{|c|}{ Month 1} & \multicolumn{3}{|c|}{ Month 2} & \multicolumn{2}{|c|}{ Month 3} & \multicolumn{3}{|c|}{ Month 4} & \multicolumn{2}{|l|}{ Month 5} & \multicolumn{3}{|c|}{ Month 6} & \multicolumn{2}{|l|}{ Month 7} & \multicolumn{2}{|c|}{ Month 8} \\
\hline & $E$ & $\mathrm{~B}$ & M & $E$ & $\theta$ & $M$ & $E$ & \begin{tabular}{l|l}
$B$ & $M$
\end{tabular} & $E$ & B & M & $E$ & B $M$ & $E$ & $\theta$ & $M$ & $E$ & \begin{tabular}{l|l}
$B$ & $M$
\end{tabular} & $E$ & $\theta$ & $M$ \\
\hline \multicolumn{22}{|c|}{$\begin{array}{l}\text { Single Family House - Architect } \\
\text { Design (3,000 square feet with full } \\
\text { basement) }\end{array}$} \\
\hline \multicolumn{22}{|c|}{ General Conditions } \\
\hline \multicolumn{22}{|c|}{ bcontractor } \\
\hline \multicolumn{22}{|l|}{ Foundation } \\
\hline \multicolumn{22}{|l|}{ Framing } \\
\hline \multicolumn{22}{|l|}{ Dry In } \\
\hline \multicolumn{22}{|l|}{ Exterior Finishes } \\
\hline \multicolumn{22}{|c|}{$\begin{array}{l}\text { Utility Rough-B97Ins and } \\
\text { Complete Concrete }\end{array}$} \\
\hline \multicolumn{22}{|l|}{ Interior Finishes } \\
\hline \multicolumn{22}{|c|}{ Landscaping and Grounds Work } \\
\hline Final Acceptance & & & & & & & & & & & & & & & & & & & & & \\
\hline
\end{tabular}

Figure A.2 Residential Custom Construction Roofing Technology Decision Points

\section{Commercial Construction}

The decision points where roof technology adoption decisions are made for commercial buildings are shown on the simplified critical path chart of construction activities in Figure A.3.

\section{Architect}

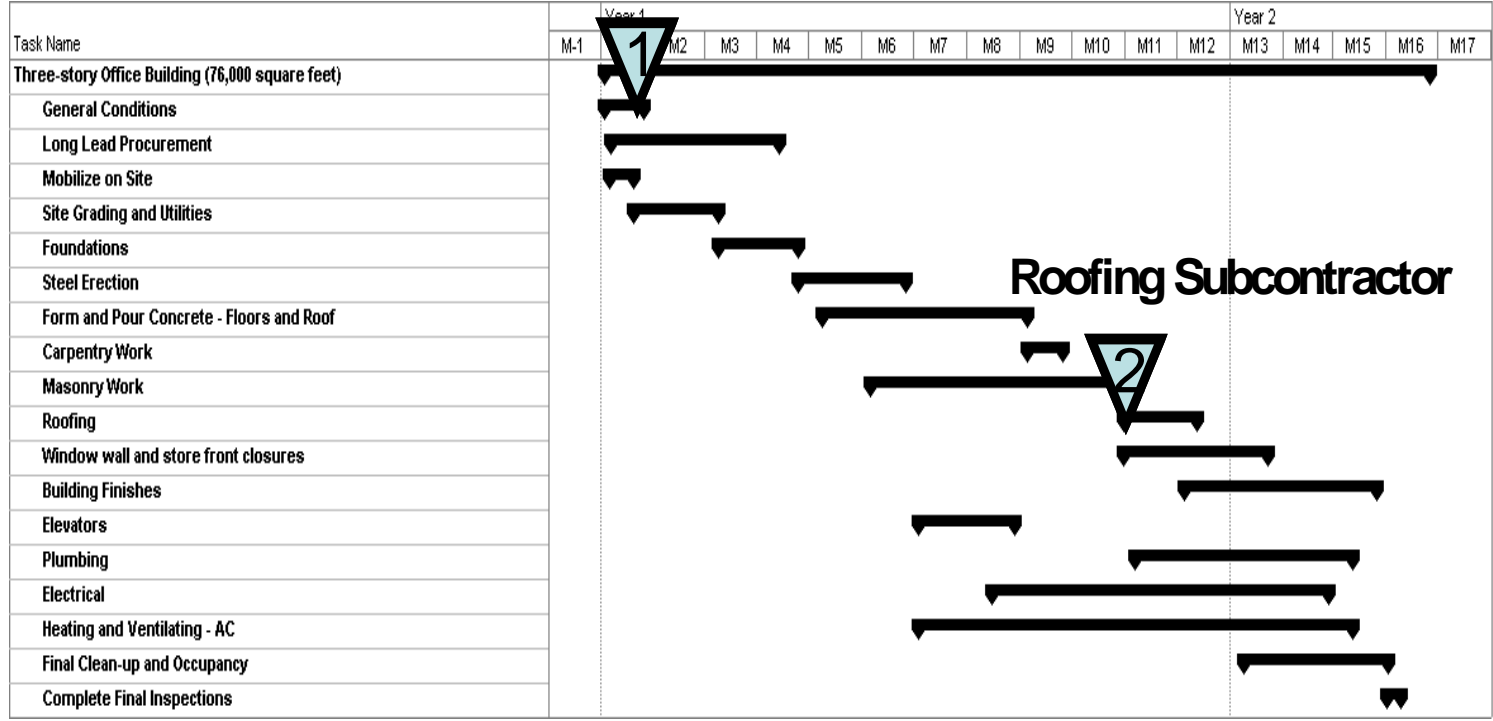

Figure A.3 Commercial Roofing Technology Decision Points

Roofing technology decisions are made in a two-step process. The architect or designer bounds the range of roofing type and material options by setting performance requirements. Influences driving the architect's roofing decisions varied somewhat by respondent, but initial cost, aesthetics, codes, and familiarity with a given roofing type were listed as the most common factors. One roofing subcontractor listed cost and logistics (material available and ease of installation) as primary decision influences. 
Roofing subcontractor responses identified their affiliation with the National Roofing Contractors Association and manufacturer data as the source of their information regarding new building technologies. In terms of industry changes, they see reflectivity performance starting to be factored into code. Most customer demand for energy efficient products are from long-term owner occupied facilities (e.g., state agencies) and high-energy users. When asked about barriers to using new innovative products, one roofing subcontractor commented that showing that new products comply with existing codes can be a problem. When asked what roofing design tools they have used, this same roofing subcontractor mentioned the Polyiso Insulation Manufacturer's Association (PIMA) "Roofwise", which calculates energy efficiency, as well the National Resources Conservation Service (NRCS) energy manual. Another roofing resource is "Guidelines for the Design of Energy Efficient Roof Systems," published by the National Roofing Contractors Association.

\section{A.2 Insulation Technology Adoption Decisions}

\section{Residential Developments and Custom Construction}

Both residential developments and residential custom construction have similar insulation decision processes, as shown by Figure A.4.

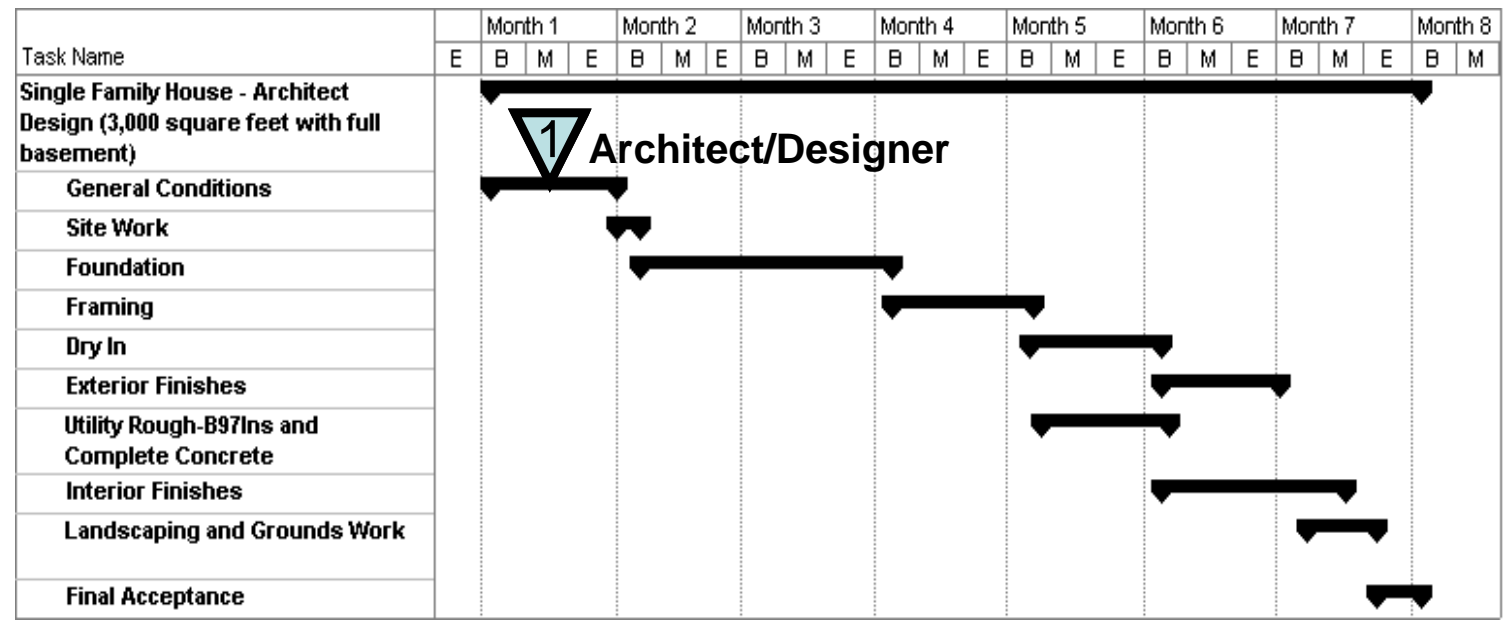

Figure A.4 Residential Construction Insulation Technology Decision Points

Code requirements and costs are the overwhelming influences on architects/designers who predominately make the decisions that determine insulation types and materials. Cost considerations resulting from the financing process also play a role in bounding the decision process. In terms of sources of information, trade publications and interactions with suppliers were named as the primary sources.

\section{Commercial Construction}

The decision points where insulation technology adoption decisions are made for commercial buildings are shown on the simplified critical path chart of construction activities in Figure A.5.

While building codes may specify a minimum R-value required for insulation, the architect/designer essentially determines the choice of insulation type and material by bounding the space availability, ventilation requirements, and the nature of construction of the building. 
Contractors have more limited options in preparing their bid proposals due to these design constraints. Code and cost considerations, in addition to the desire to work with proven products with which the architect is familiar, were listed as significant decision influences.

\section{Architect}

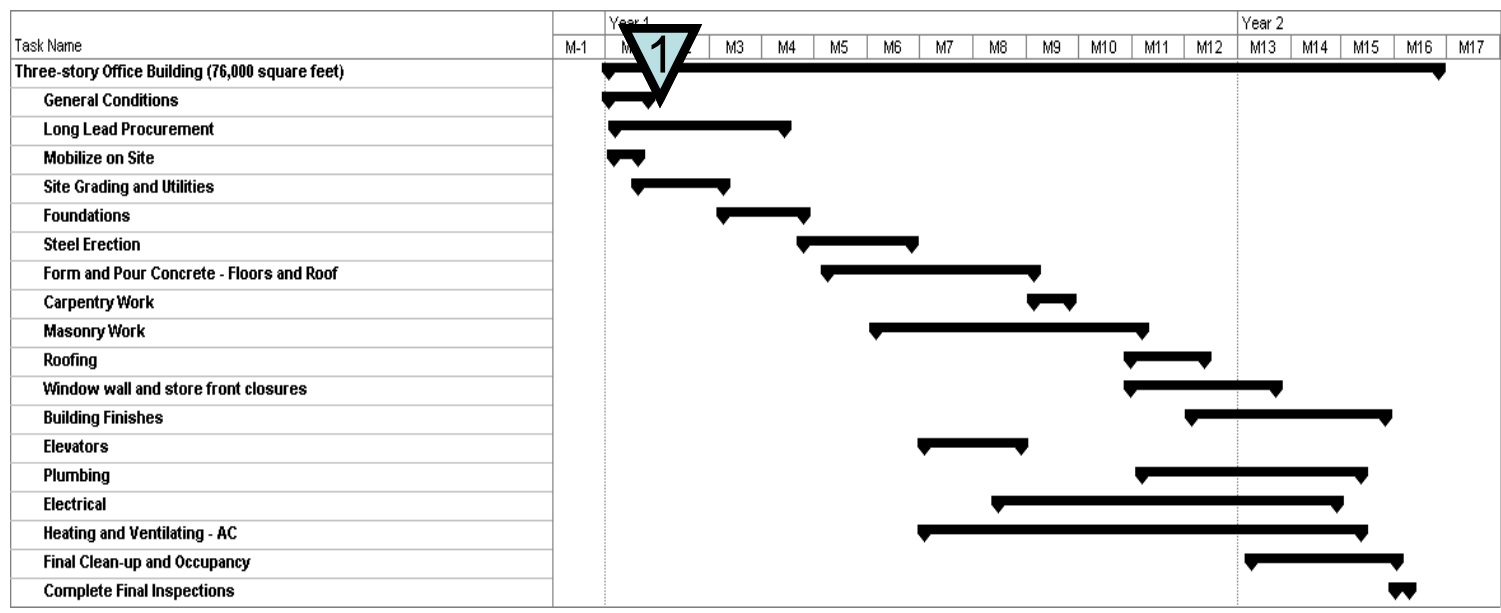

Figure A.5 Commercial Insulation Technology Decision Point

\section{A.3 Window Technology Adoption Decisions}

\section{Residential Developments}

The decision points where window technology adoption decisions are made for residential developments are shown on the simplified critical path chart of construction activities in Figure A.6.

The architect as part of the design process determines the size, general type and number of windows. Aesthetics, code requirements, and cost are key influences on the architect's decision process. Window subcontractors are responsible for final window selection as part of their bid process. Contractor window decision influences primarily consist of cost and availability.

\begin{tabular}{|c|c|c|c|c|c|c|c|c|c|c|c|c|c|c|c|c|c|c|c|c|c|c|}
\hline \multirow[b]{2}{*}{ Task Name } & \multicolumn{3}{|c|}{ Month 1} & \multicolumn{3}{|c|}{ Month 2} & \multicolumn{3}{|c|}{ Month 3} & \multicolumn{3}{|c|}{ Month 4} & \multicolumn{3}{|c|}{ Month 5} & \multicolumn{3}{|c|}{ Month 6} & \multicolumn{2}{|l|}{ Month 7} & \multicolumn{2}{|c|}{ Month 8} \\
\hline & $E$ & B $\mathrm{M}$ & $E$ & $\mathrm{~B}$ & $M$ & $\mathrm{E}$ & $\mathrm{B}$ & $M$ & $E$ & B & $M$ & $\mathrm{E}$ & $\mathrm{B}$ & $M$ & $E$ & B & $M$ & $E$ & \begin{tabular}{|l|l|}
$\mathrm{B}$ & $\mathrm{M}$ \\
\end{tabular} & $E$ & $\mathrm{~B}$ & $M$ \\
\hline \multicolumn{23}{|c|}{$\begin{array}{l}\text { Single Family House - Architect } \\
\text { Design (3,000 square feet with full } \\
\text { basement) }\end{array}$} \\
\hline \multicolumn{23}{|c|}{ General Conditions } \\
\hline \multicolumn{23}{|l|}{ Site Work } \\
\hline \multicolumn{23}{|l|}{ Foundation } \\
\hline \multicolumn{23}{|l|}{ Framing } \\
\hline \multicolumn{23}{|l|}{ Dry In } \\
\hline \multicolumn{23}{|l|}{ Exterior Finishes } \\
\hline \multicolumn{23}{|c|}{$\begin{array}{l}\text { Utility Rough-B97lns and } \\
\text { Complete Concrete }\end{array}$} \\
\hline \multicolumn{23}{|l|}{ Interior Finishes } \\
\hline \multicolumn{23}{|c|}{ Landscaping and Grounds Work } \\
\hline Final Acceptance & & & & & & & & & & & & & & & & & & & & & & \\
\hline
\end{tabular}

Figure A.6 Residential Development Window Technology Decision Points 


\section{Residential Custom Construction}

Owners influence both the architect decisions as well as the window subcontractor's decisions in custom residential construction. Brand names become more of a decision influence in terms of the type of windows selected. Again, aesthetics and cost are key influences.

\section{Commercial Construction}

Commercial construction interview respondents indicated that architect/designers primarily make the window technology decisions for commercial buildings, as shown by Figure A.7. Aesthetics, heat gain/loss, solar heat gain coefficient, and cost were identified as the primary influences driving window design decisions. Flexibility in sizing was also listed as a desirable attribute when selecting different window types.

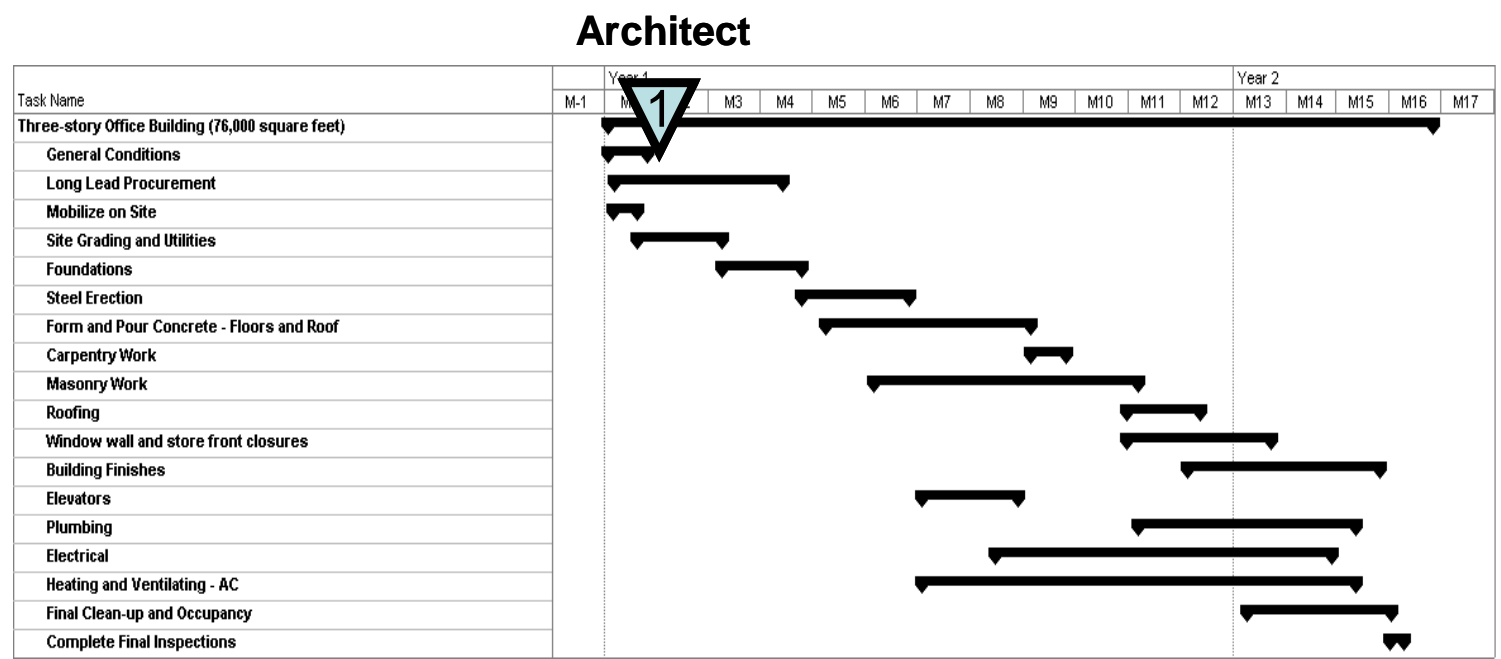

Figure A.7 Commercial Window Technology Decision Point

\section{A.4 Space Condition/HVAC System Technology Adoption Decisions}

\section{Residential Developments}

The decision points where HVAC technology adoption decisions are made for residential developments are shown on the simplified critical path chart of construction activities in Figure A.8.

Although the architect/designer may bind the type of space conditioning/HVAC options that are viable, in most cases it is the subcontractor who determines the type of equipment to be installed. First costs are a primary decision influence as subcontractors are competing primarily on costs for the work. 


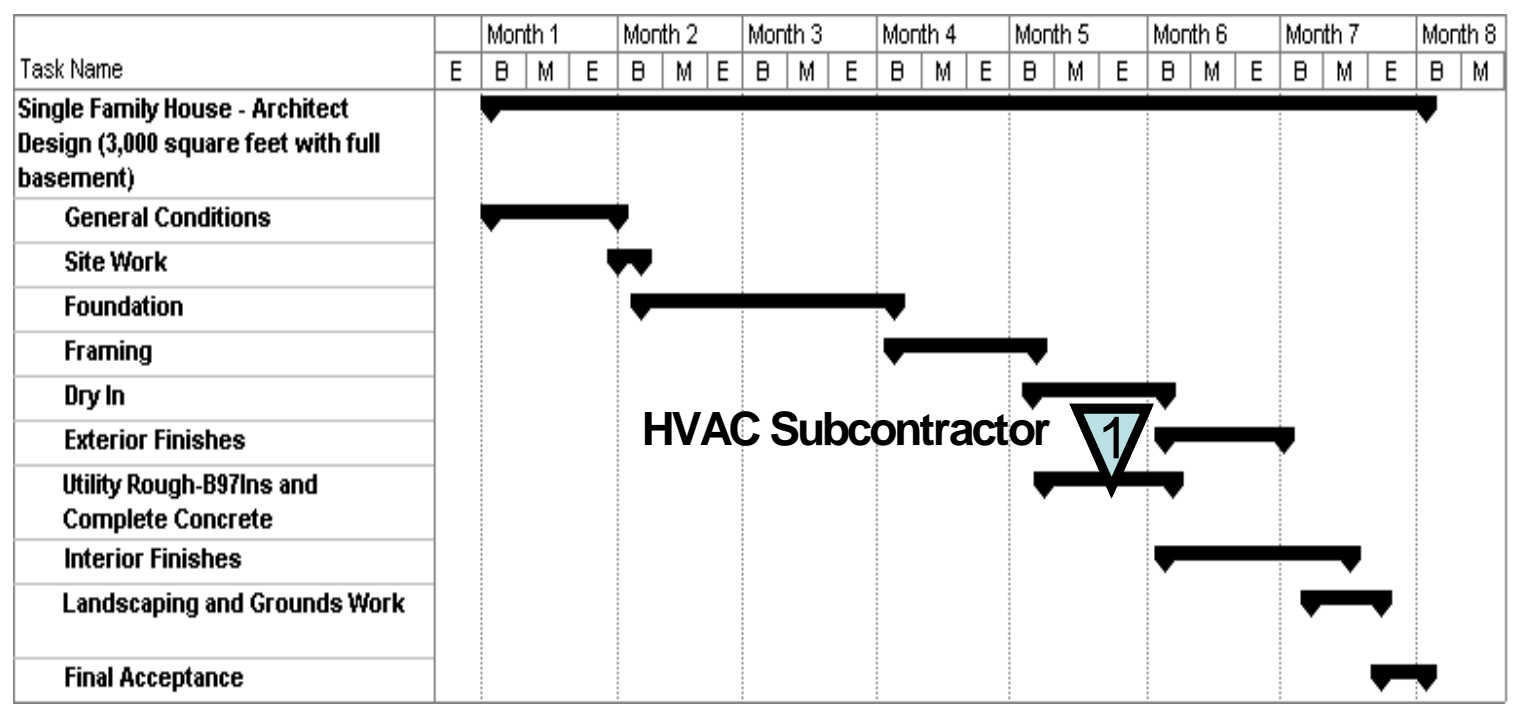

Figure A.8 Residential Development HVAC Technology Decision Point

\section{Residential Custom Construction}

Owners have much greater influence on subcontractor's decisions for residential custom construction. Decision influences move from first costs to life-cycle costs as energy efficiency and system maintenance (e.g., features, filtration, humidification) are given more consideration.

\section{Commercial Construction}

Commercial construction interview respondents indicated that architect/designers primarily make the space condition/HVAC technology decisions for commercial buildings, as shown by Figure A.9. Costs and codes were the overwhelming decision influences on the space condition/HVAC technology selection process. One mechanical contractor that also performed design work stated that industry organizations and trade shows (e.g., SMACNA), vendors, and publications (Consulting Engineer, PM Engineering, etc.) were the primary sources of information used to formulate designs and recommendations. When asked what the best way to introduce new technology was, they responded with training/demonstration of the new technology, combined with changes to building codes. They responded that cost effectiveness was the principal barrier faced by many new technologies. 


\section{Architect/Design Team}

\begin{tabular}{|l|}
\hline \multirow{2}{*}{ Task Name } \\
\hline Three-story Office Building (76,000 square feet) \\
\hline General Conditions \\
\hline Long Lead Procurement \\
\hline Mobilize on Site \\
\hline Site Grading and Utilities \\
\hline Foundations \\
\hline Steel Erection \\
\hline Form and Pour Concrete - Floors and Roof \\
\hline Carpentry Work \\
\hline Masonry Work \\
\hline Roofing \\
\hline Window wall and store front closures \\
\hline Building Finishes \\
\hline Elevators \\
\hline Plumbing \\
\hline Electrical \\
\hline Heating and Ventilating - AC \\
\hline Final Clean-up and Occupancy \\
\hline Complete Final Inspections \\
\hline
\end{tabular}

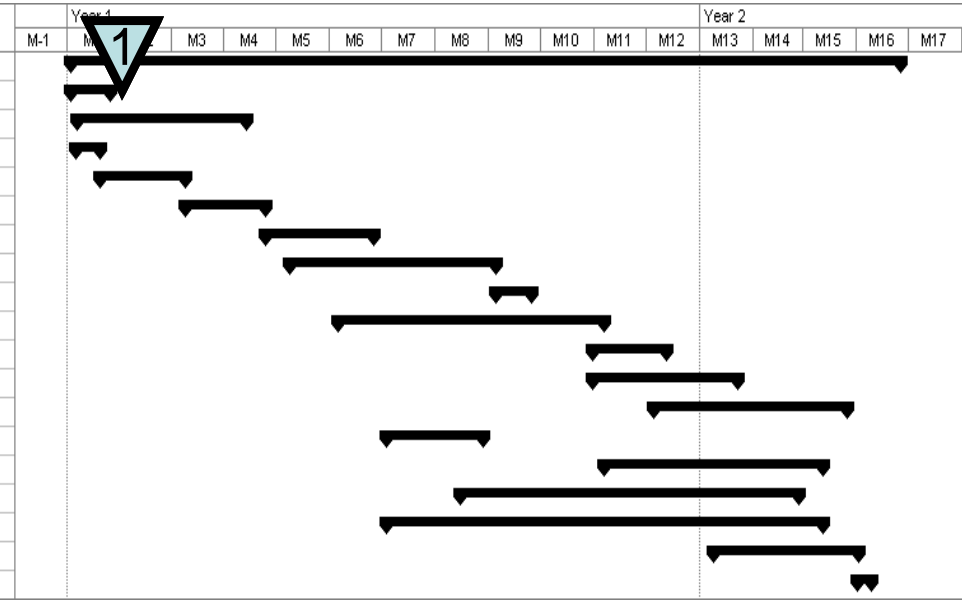

Figure A.9 Commercial HVAC Technology Decision Point

\section{A.5 Water Heater Technology Adoption Decisions}

\section{Residential Developments and Custom Construction}

The decision point where water heater technology adoption decisions are made for residential developments and custom construction are shown on the simplified critical path chart of construction activities in Figure A.10.

Most interviewees responded that subcontractors largely determine the type of water heaters installed, and that costs and performance (with costs being first) are the primary decision influences. This is mainly due to the bid process used to select subcontractors.

\begin{tabular}{|c|c|c|c|c|c|c|c|c|c|c|c|c|c|c|c|c|c|c|c|c|c|c|c|c|}
\hline \multirow[b]{2}{*}{ Task Name } & \multicolumn{4}{|c|}{ Month 1} & \multicolumn{3}{|c|}{ Month 2} & \multicolumn{3}{|c|}{ Month 3} & \multicolumn{3}{|c|}{ Month 4} & \multicolumn{3}{|c|}{ Month 5} & \multicolumn{3}{|c|}{ Month 6} & \multicolumn{3}{|c|}{ Month 7} & \multicolumn{2}{|c|}{ Month 8} \\
\hline & $E$ & 日 & M & $E$ & $\mathrm{~B}$ & $M$ & $E$ & $\mathrm{~B}$ & $M$ & $E$ & B & $\mathrm{M}$ & $E$ & $\mathrm{~B}$ & $\mathrm{M}$ & $E$ & $\mathrm{~B}$ & $M$ & $E$ & $\mathrm{~B}$ & $M$ & $E$ & B & $M$ \\
\hline $\begin{array}{l}\text { Single Family House - } \\
\text { Design (3,000 square } \\
\text { basement) }\end{array}$ & & & & & & & & & & & & & & & & & & & & & & & & \\
\hline General Conditior & & & & & & & & & & & & & & & & & & & & & & & & \\
\hline Site Work & & & & & & & & & & & & & & & & & & & & & & & & \\
\hline Foundation & & & & & & & & & & & & & & & & & & & & & & & & \\
\hline Framing & & & & & & & & & & & & & & & & & & & & & & & & \\
\hline Dry In & & & & & & & & & & & & & & & & & & & & & & & & \\
\hline Exterior Finishes & & & & & & & & & & & & & & & & & & & & & & & & \\
\hline $\begin{array}{l}\text { Utility Rough-B97| } \\
\text { Complete Concre }\end{array}$ & & & & & & & & & & & & & & & & & & & & & & & & \\
\hline Interior Finishes & & & & & & & & & & & & & & & & & & & & & & & & \\
\hline Landscaping and & & & & & & & & & & & & & & & & & & & & & & & & \\
\hline Final Acceptance & & & & & & & & & & & & & & & & & & & & & & & & \\
\hline
\end{tabular}

Figure A.10 Residential Construction Water Heater Technology Decision Point

\section{Commercial Construction}

Commercial construction interview respondents indicated that architect/design engineers primarily make the water heater technology decisions for commercial buildings, as shown by 
Figure A.11. Interviewees indicated that commercial building designers constrained the selection of water heater technology options much more than in the case of residential construction. Outside of energy source options, meeting code requirements and first cost are the principal decision influences.

Architect/Design Team

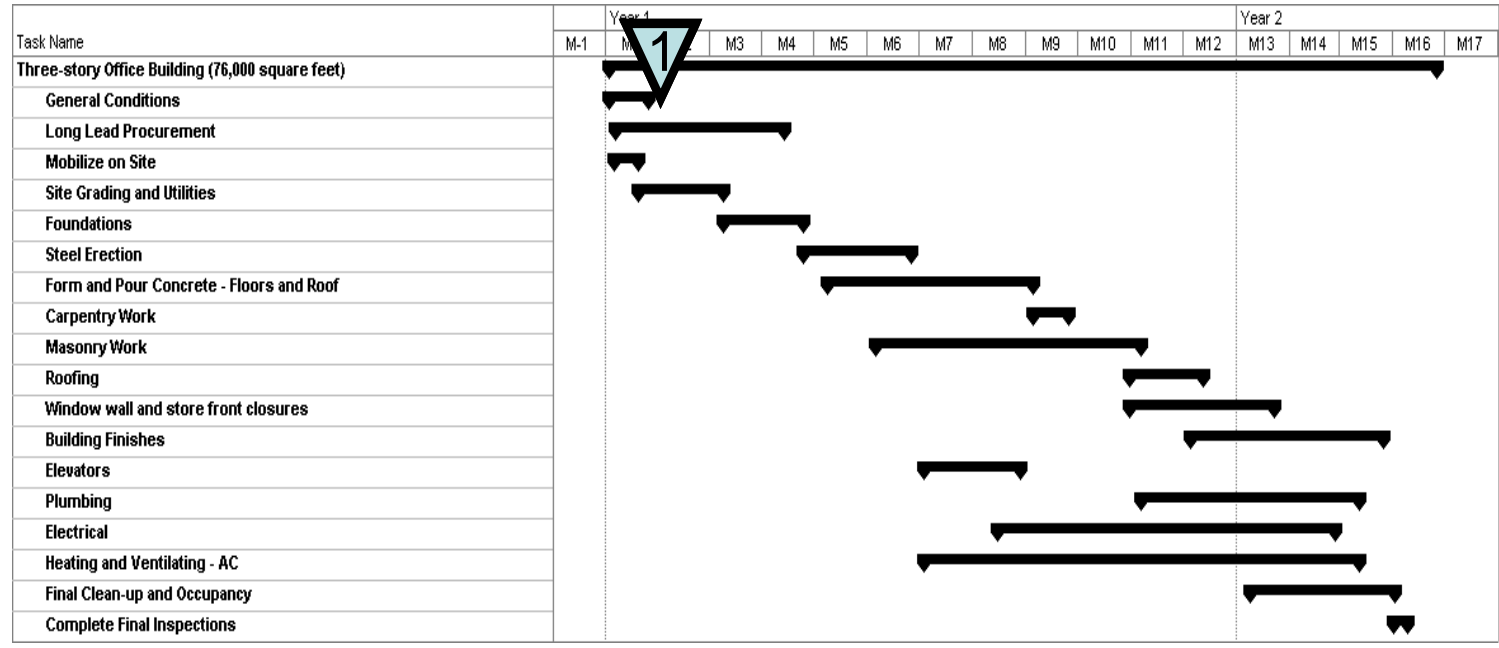

Figure A.11 Commercial Construction Water Heater Technology Decision Point

\section{A.6 Lighting Technology Adoption Decisions}

\section{Residential Developments and Custom Construction}

The decision point where lighting technology adoption decisions are made for residential developments and custom construction are shown on the simplified critical path chart of construction activities in Figure A.12.

The principal drivers influencing the selection of lighting technology for residential construction are aesthetics and costs. Subcontractors and their suppliers have somewhat greater influence on lighting decisions than in commercial construction. The developer and owner (if custom construction) have significant influence in lighting decisions. In general, contractors indicated that most of their information comes for their subcontractors and suppliers. Other sources such as trade journals have less influence. Cost, availability, and the amount of time and degree of difficulty associated with installation are all barriers to using new products. 


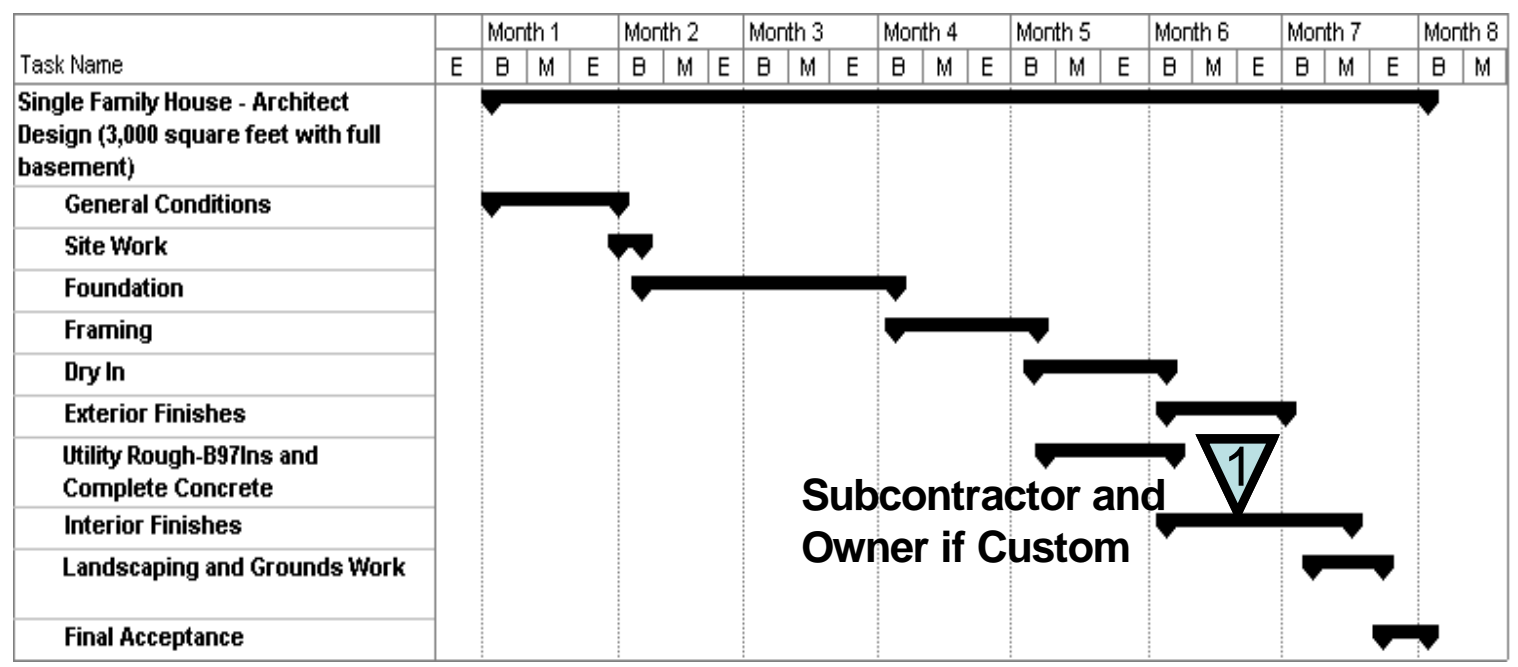

Figure A.12 Residential Construction Lighting Technology Decision Point

\section{Commercial Construction}

Commercial construction interview respondents indicated that architect/electrical design engineers primarily make the lighting technology decisions for commercial buildings, as shown by Figure A.13. Interviewees indicated that commercial building designers constrained the selection of lighting technology options much more than in the case of residential construction. The main decision influences are initial costs, code, aesthetics, and energy efficiency.

The main barriers to new product adoption were identified as technology being perceived as unproven and/or high first costs resulting in a long payback to owner.

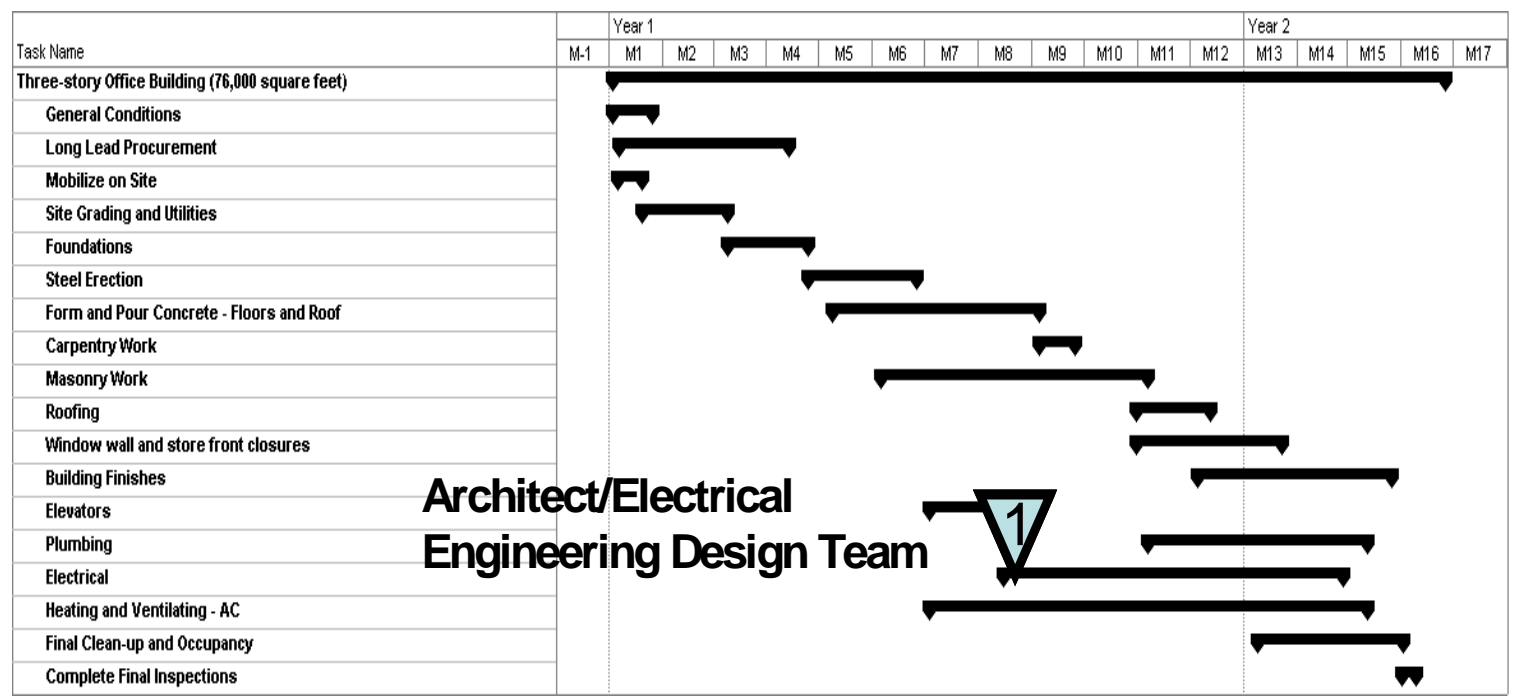

Figure A.13 Commercial Construction Lighting Technology Decision Point 


\section{A.7 Appliance Technology Adoption Decisions}

\section{Residential Developments}

The decision points where appliance technology adoption decisions are made for residential developments are shown on the simplified critical path chart of construction activities in Figure A.14.

Developers establish the general price class for the development (e.g., economy, mid-level, luxury). This bounds the general type of appliances expected in terms of cost, quality, and features. Working within these bounds, subcontractors determine the actual products as part of the bid process. Subcontractors are influenced by not only their margins, but also by the level of familiarity with the products. Subcontractors give preference to those products that are fast and easy to install, and require minimum training of crews to complete. Appliance availability is also a factor, as delays can be costly.

\begin{tabular}{|c|c|c|c|c|c|c|c|c|c|}
\hline \multirow{2}{*}{ Task Name } & & Month 1 & Morth 2 & Month 3 & Month 4 & Month 5 & Morth 6 & Month 7 & Month 8 \\
\hline & $E$ & \begin{tabular}{|l|l|l}
$\mathrm{B}$ & $\mathrm{M}$ & $\mathrm{B}$ \\
\end{tabular} & \begin{tabular}{|l|l|l}
$B$ & $M$ & $E$ \\
\end{tabular} & \begin{tabular}{|l|l|l}
$B$ & $M$ & $E$ \\
\end{tabular} & \begin{tabular}{l|l|l}
$B$ & $M$ & $E$ \\
\end{tabular} & \begin{tabular}{l|l|l|}
$B$ & $M$ & $E$ \\
\end{tabular} & \begin{tabular}{|l|l|l|} 
B & M & E \\
\end{tabular} & \begin{tabular}{|l|l|l}
$\mathrm{B}$ & $\mathrm{M}$ & $\mathrm{E}$ \\
\end{tabular} & $\begin{array}{lll} & \text { O M } \\
\end{array}$ \\
\hline $\begin{array}{l}\text { Single Family House - Architect } \\
\text { Design (3,000 square feet with full } \\
\text { basement) }\end{array}$ & & 1 & $\begin{array}{l}\text { Deve } \\
\text { Price }\end{array}$ & $\begin{array}{l}\text { loper } \\
\text { e Class }\end{array}$ & Establis & $\begin{array}{l}\text { shes } \\
\text { jildinas }\end{array}$ & & & \\
\hline General Conditions & & & & & & & & & \\
\hline Site Work & & & & & & & & & \\
\hline Foundation & & & & & & & & & \\
\hline Framing & & & & & & & & & \\
\hline Dry In & & & & & & & & & \\
\hline Exterior Finishes & & & & & & & & & \\
\hline $\begin{array}{l}\text { Utility Rough-B97lns and } \\
\text { Complete Concrete }\end{array}$ & & & & Subc & ontract & tor lde & 1у & & \\
\hline Interior Finishes & & & & Spec & ific Pro & ducts & & & \\
\hline Landscaping and Grounds Work & & & & & & & & & \\
\hline Final Acceptance & & & & & & & & & \\
\hline
\end{tabular}

Figure A.14 Residential Development Appliance Technology Decision Points

\section{Residential Custom Construction}

Owners drive the appliance decision process for custom construction (as shown by Figure A.15). Features, aesthetics, and to some extent energy efficiency are all factors influencing the decision process. 


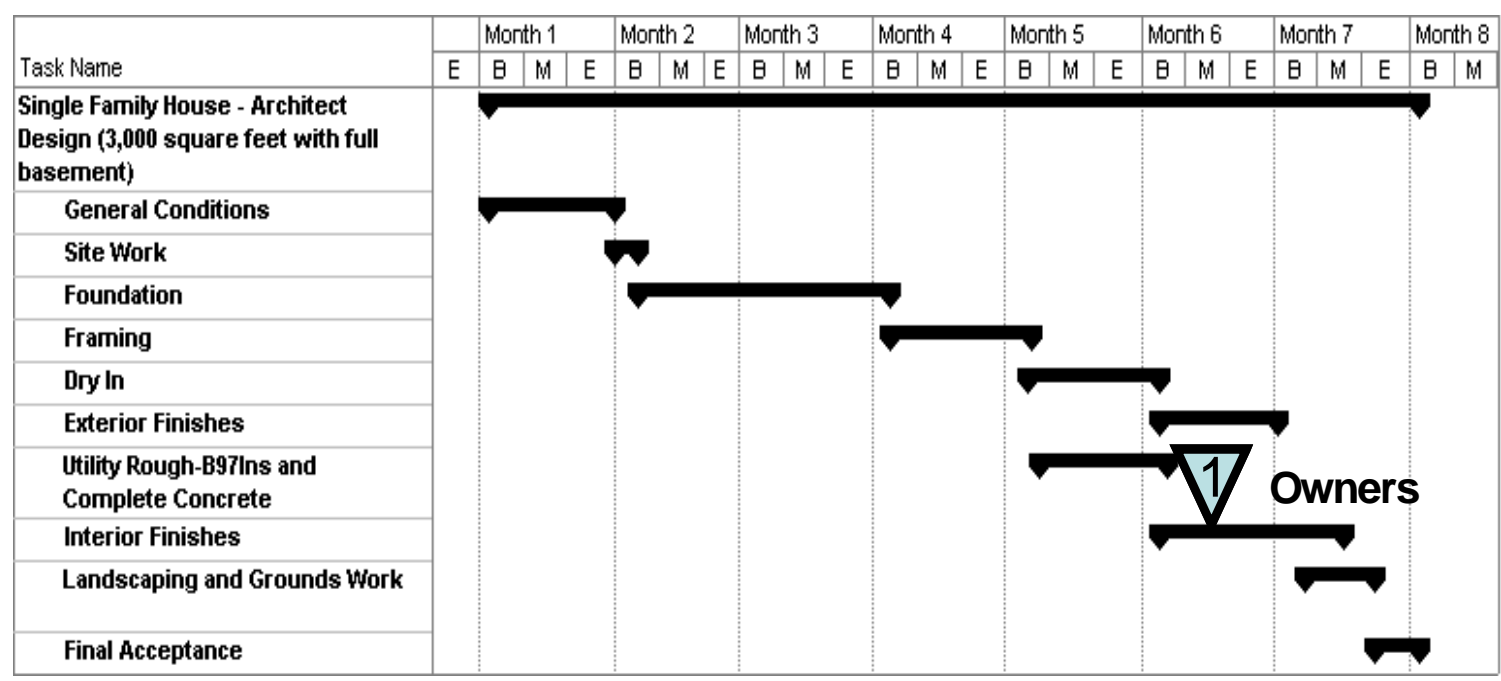

Figure A.15 Residential Custom Construction Appliance Technology Decision Point

\section{Commercial Construction}

Commercial construction interview respondents indicated that the architect or design team is responsible for the appliance technology decisions for commercial buildings, as shown by Figure A.16. Codes and costs, plus working with known models of interest or products, were all identified as decision influences.

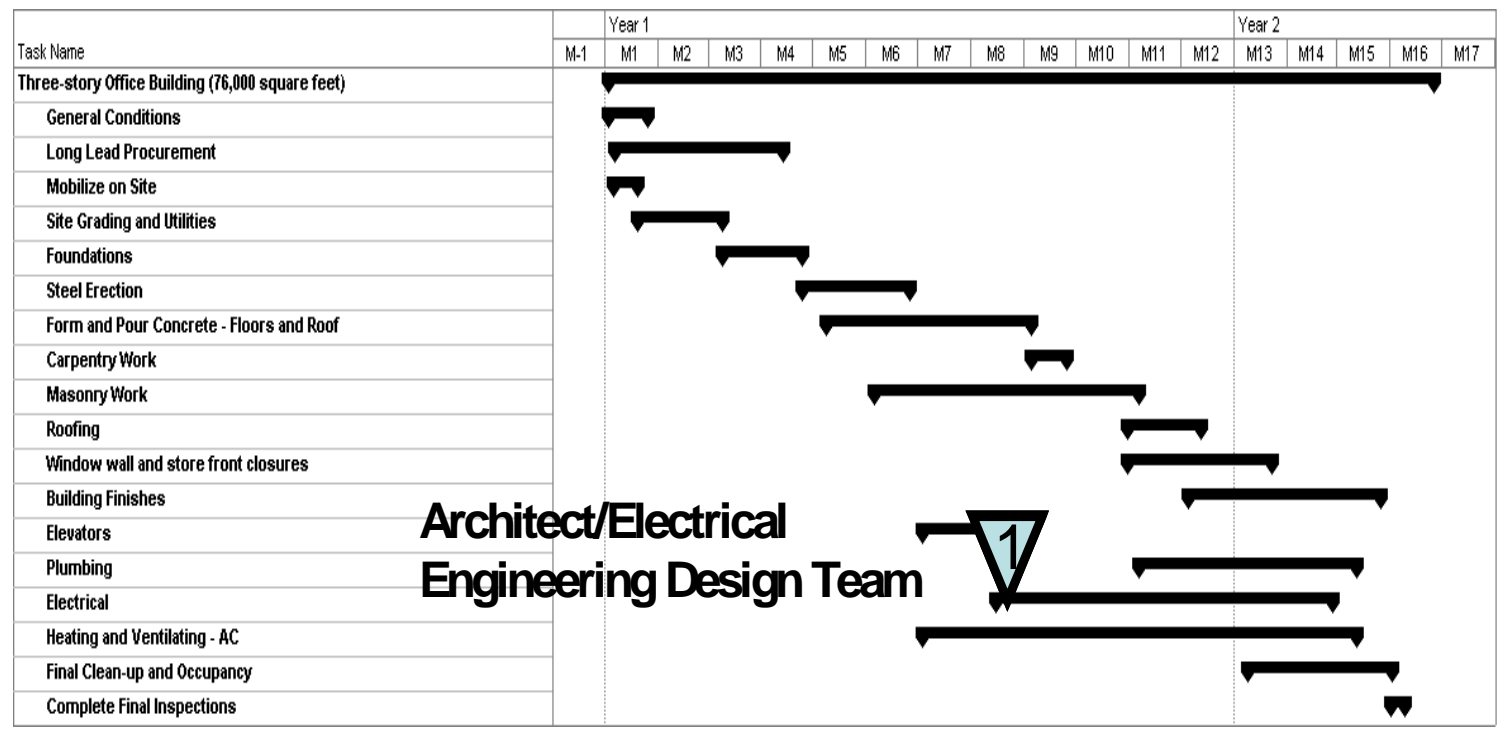

Figure A.16 Commercial Construction Appliance Technology Decision Point

\section{A.8 Landscaping Technology Adoption Decisions}

Only one landscape architect was interviewed, although other interviewees provided information, from their perspective, on landscaping decisions. Developers/owners were identified as the decision makers for both residential and commercial buildings. Developer/owners decision influences in both cases were first cost and aesthetics, although designs that aid energy efficiency or sustainability are starting to emerge as a selling point. The landscape architect and supporting 
contractors give preference to proven products that are readily available. Sources of new landscaping related technology information include professional organizations, trade journals, and vendor supplied information. 


\section{Appendix B: Residential Construction Critical Path Framework}

Figure B.1 illustrates the construction steps associated with a single-family house (3,000 square feet with full basement). There are 88 steps in the design, permitting, and construction process. These steps are representative of the typical steps associated with a residential custom home. 


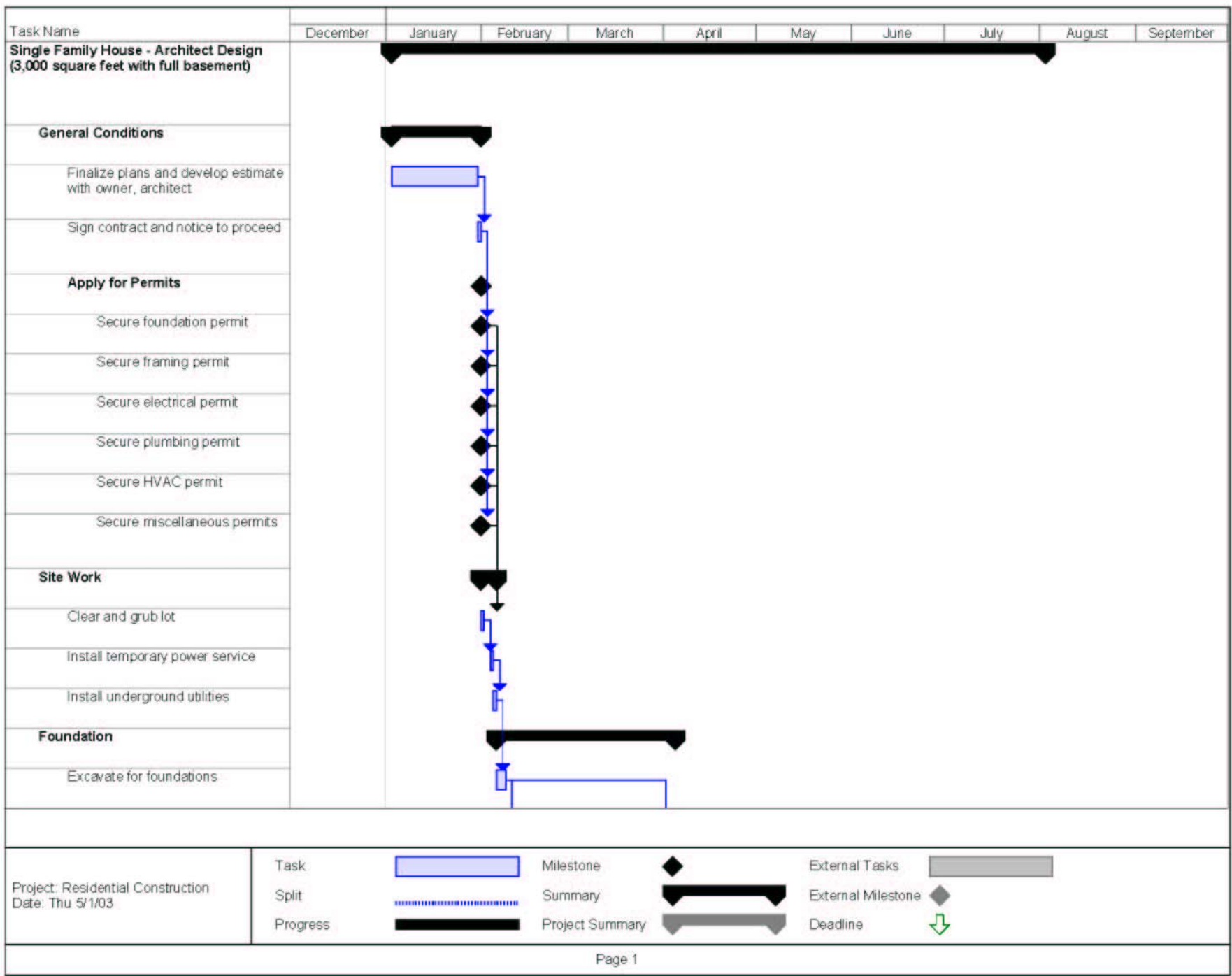

Figure B.1 Residential Construction Steps 


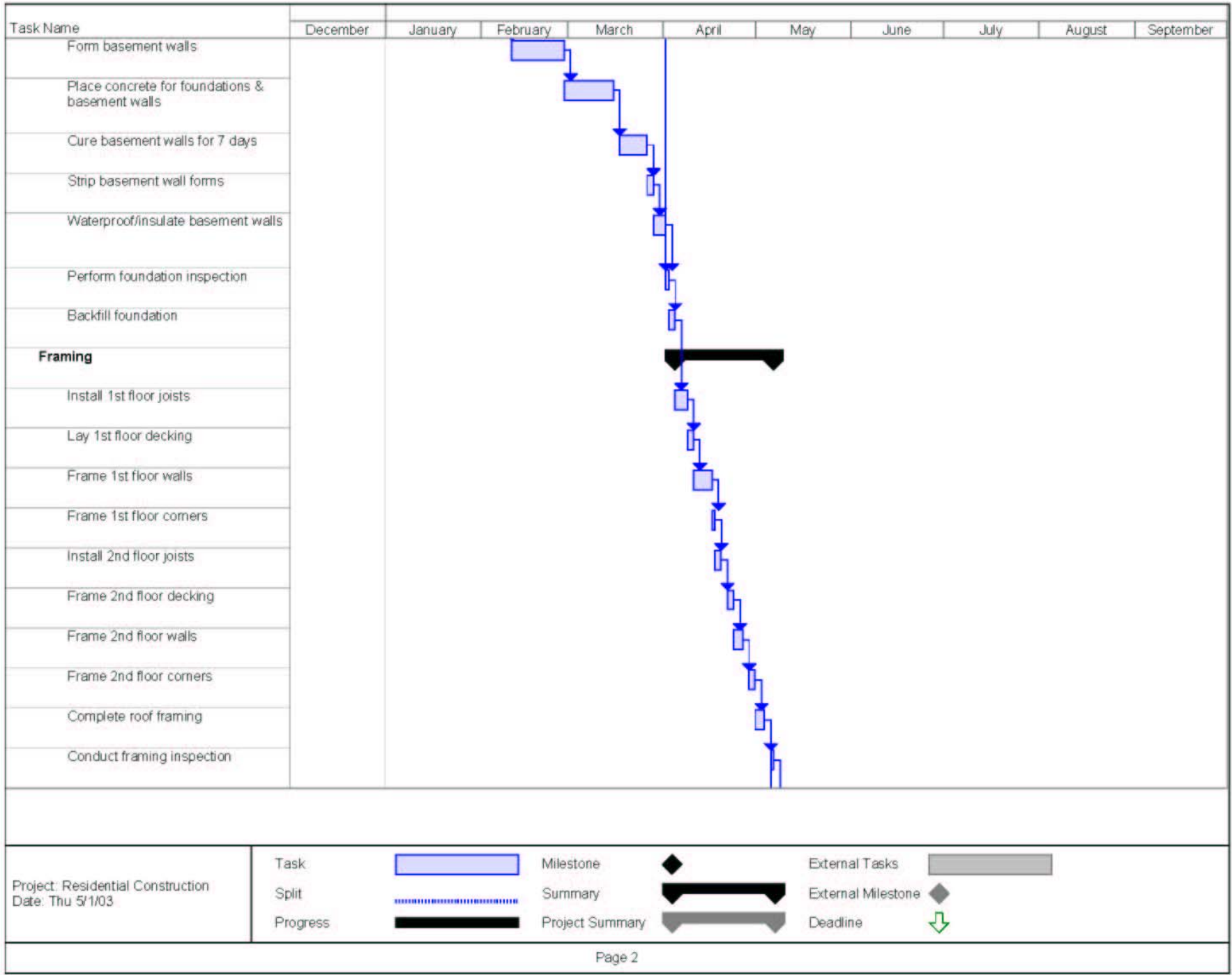

Figure B.1 Residential Construction Steps, continued. 


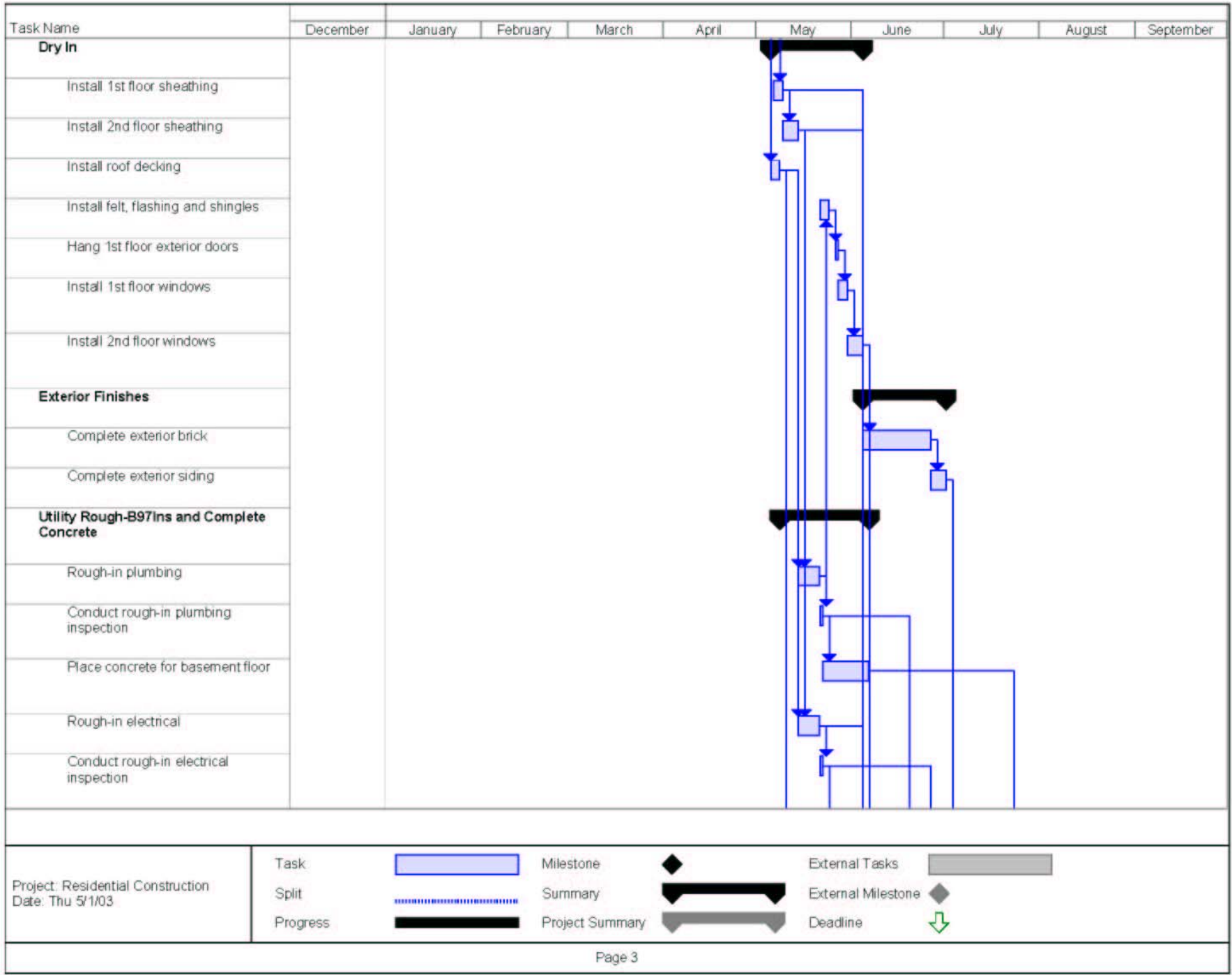

Figure B.1 Residential Construction Steps, continued. 


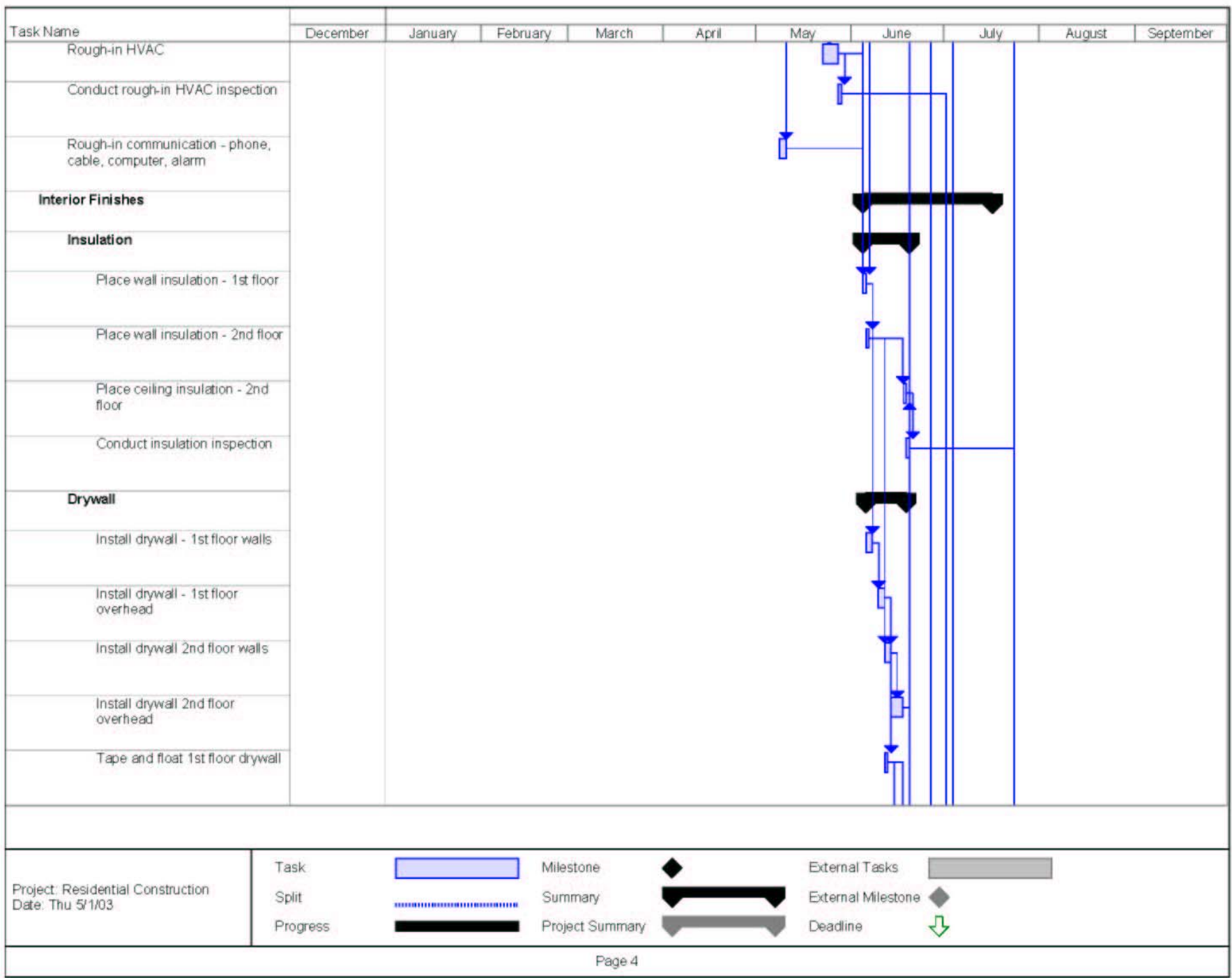

Figure B.1 Residential Construction Steps, continued. 


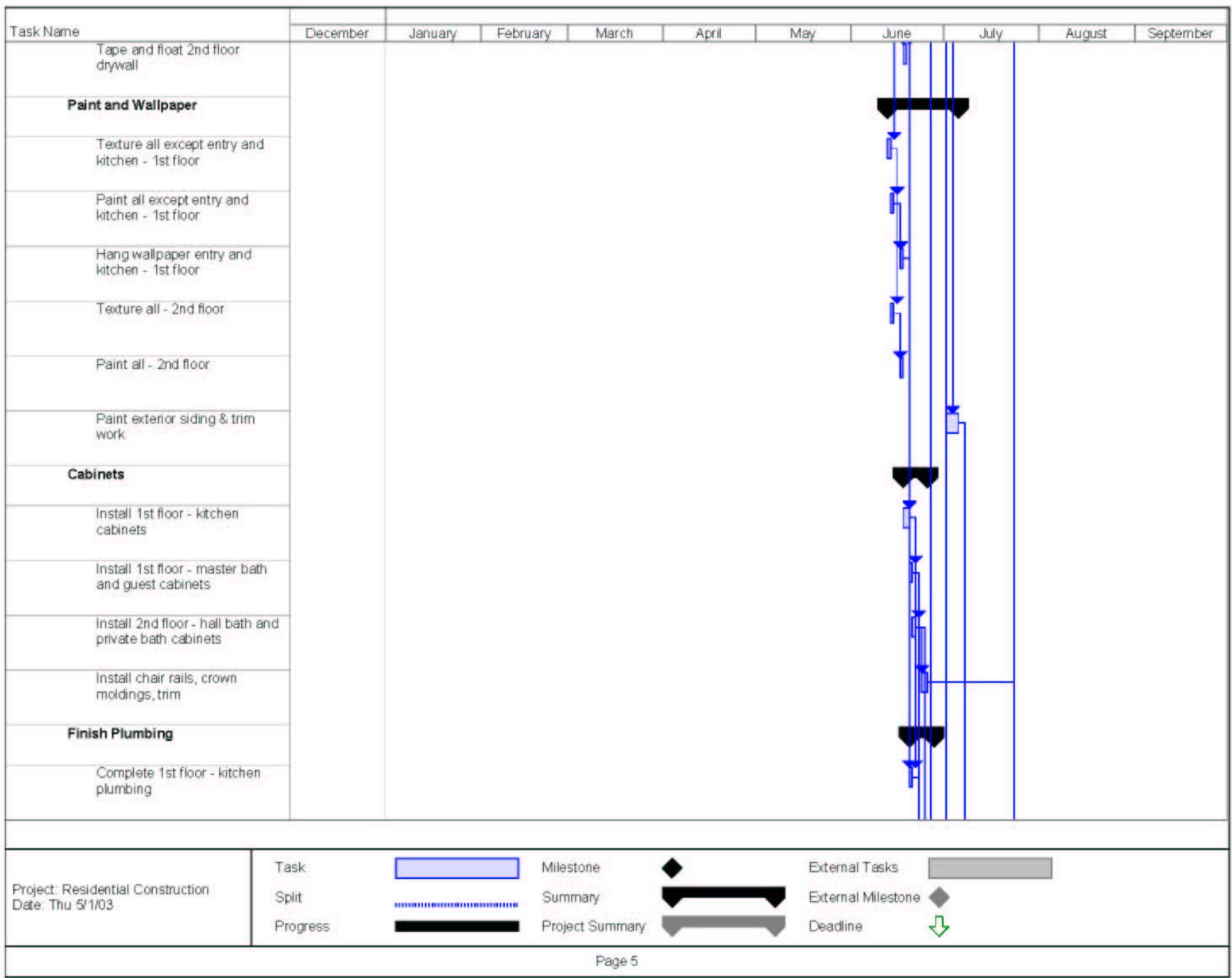

Figure B.1 Residential Construction Steps, continued. 


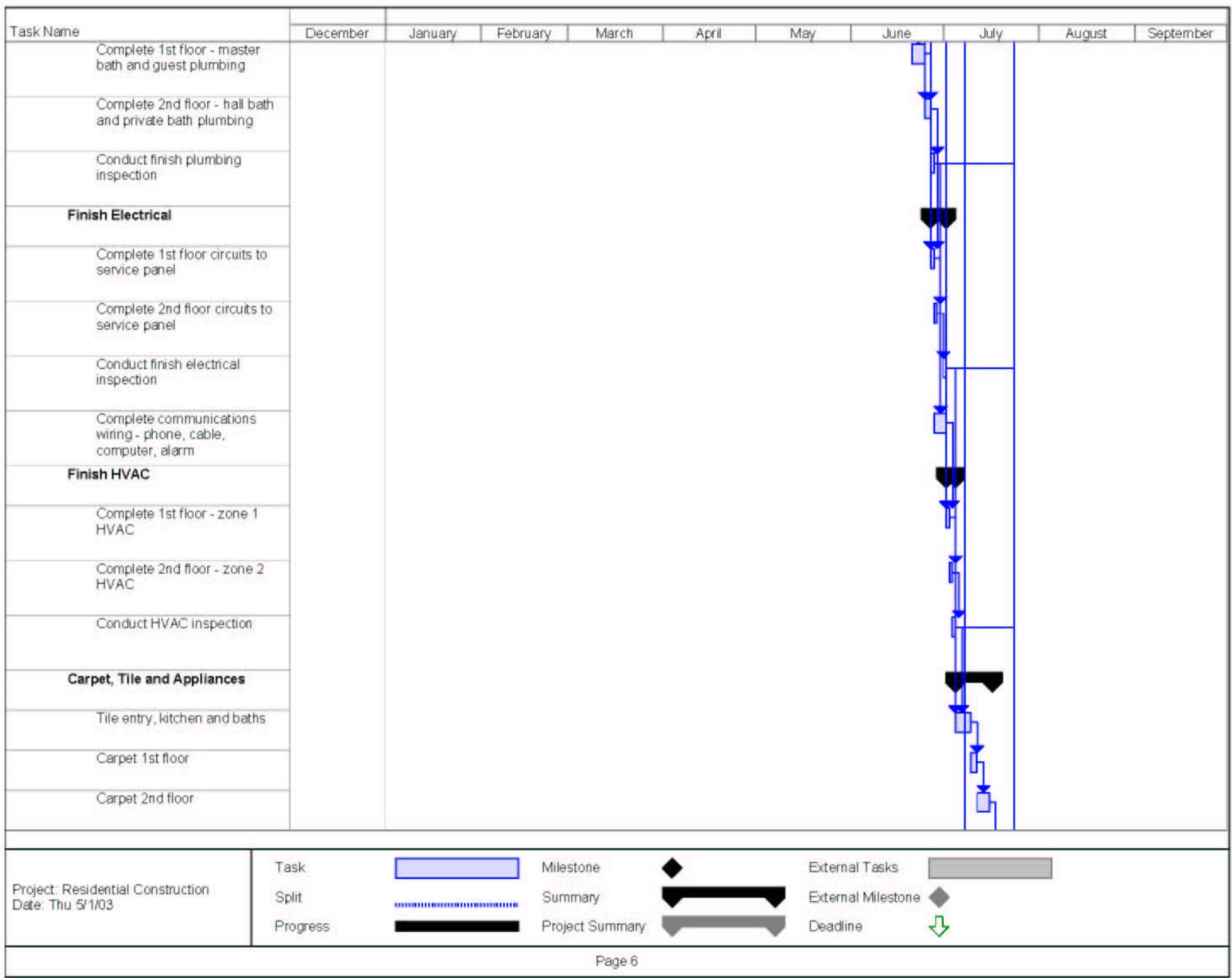

Figure B.1 Residential Construction Steps, continued. 


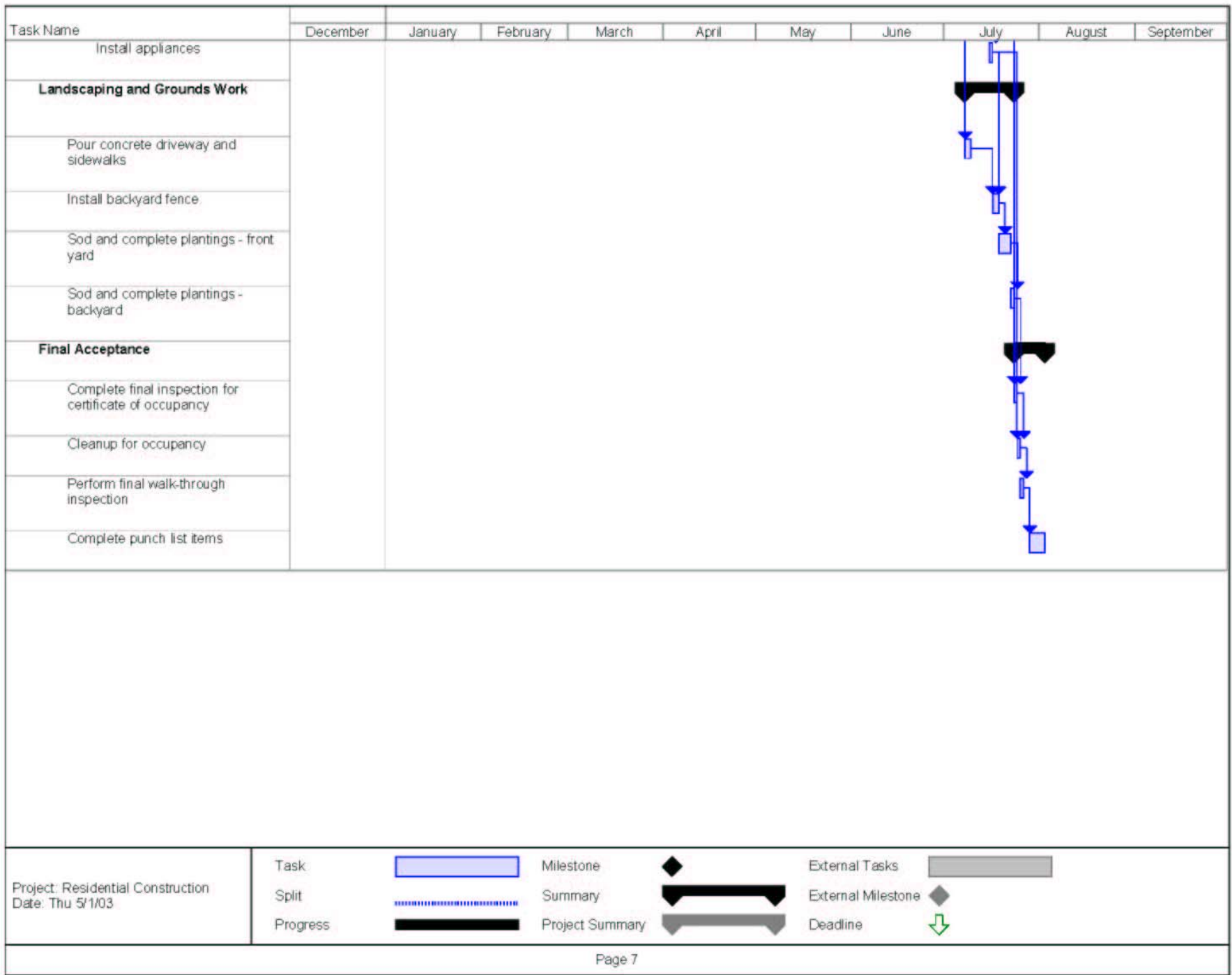

Figure B.1 Residential Construction Steps, continued. 


\section{Appendix C: Commercial Construction Critical Path Framework}

Figure C.1 illustrates the construction steps associated with a three-story office building (76,000 square feet). There are 126 steps in the permitting and construction process (design steps are not shown). These steps are representative of the typical steps associated with a commercial office building 


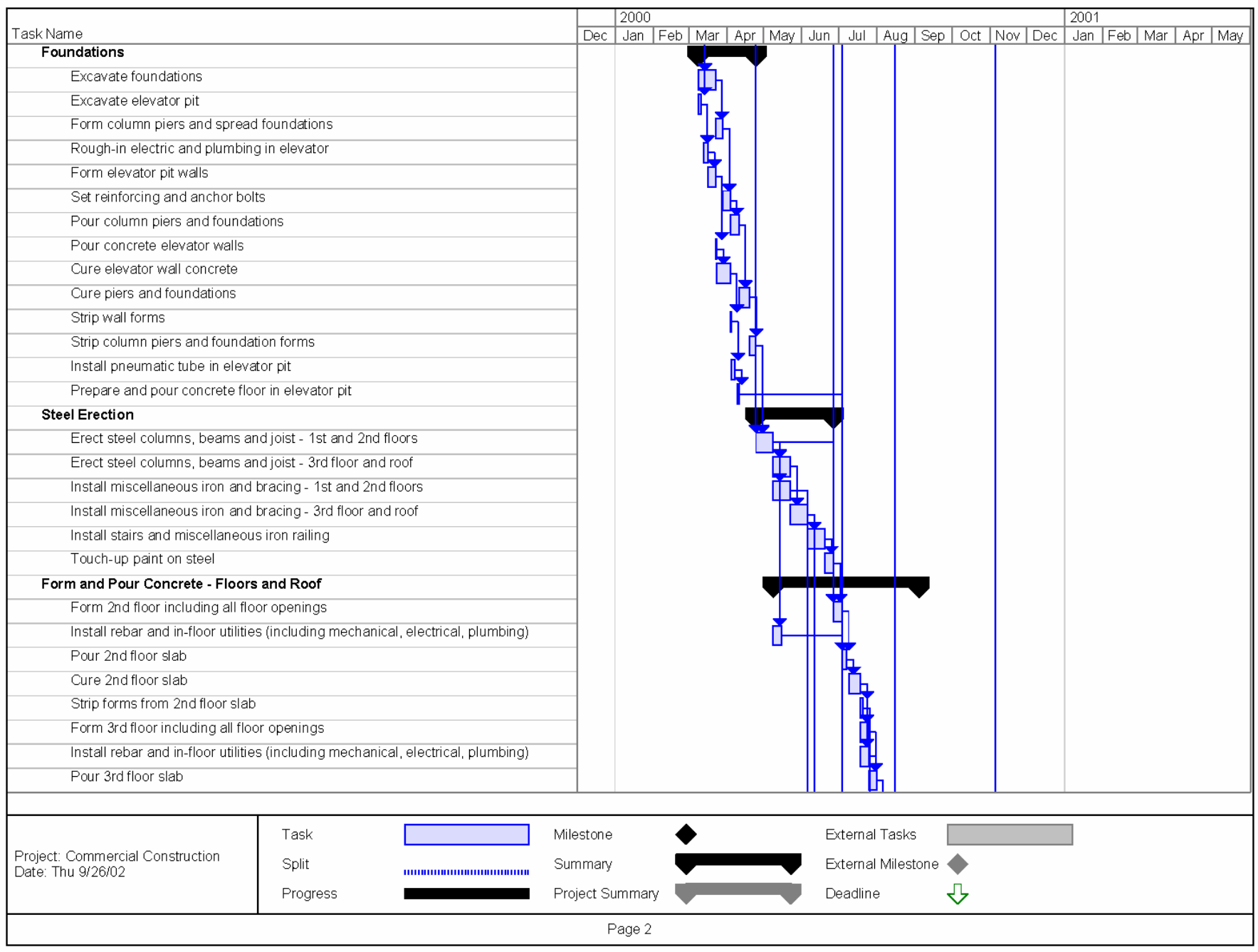

Figure C.1 Commercial Construction Steps 


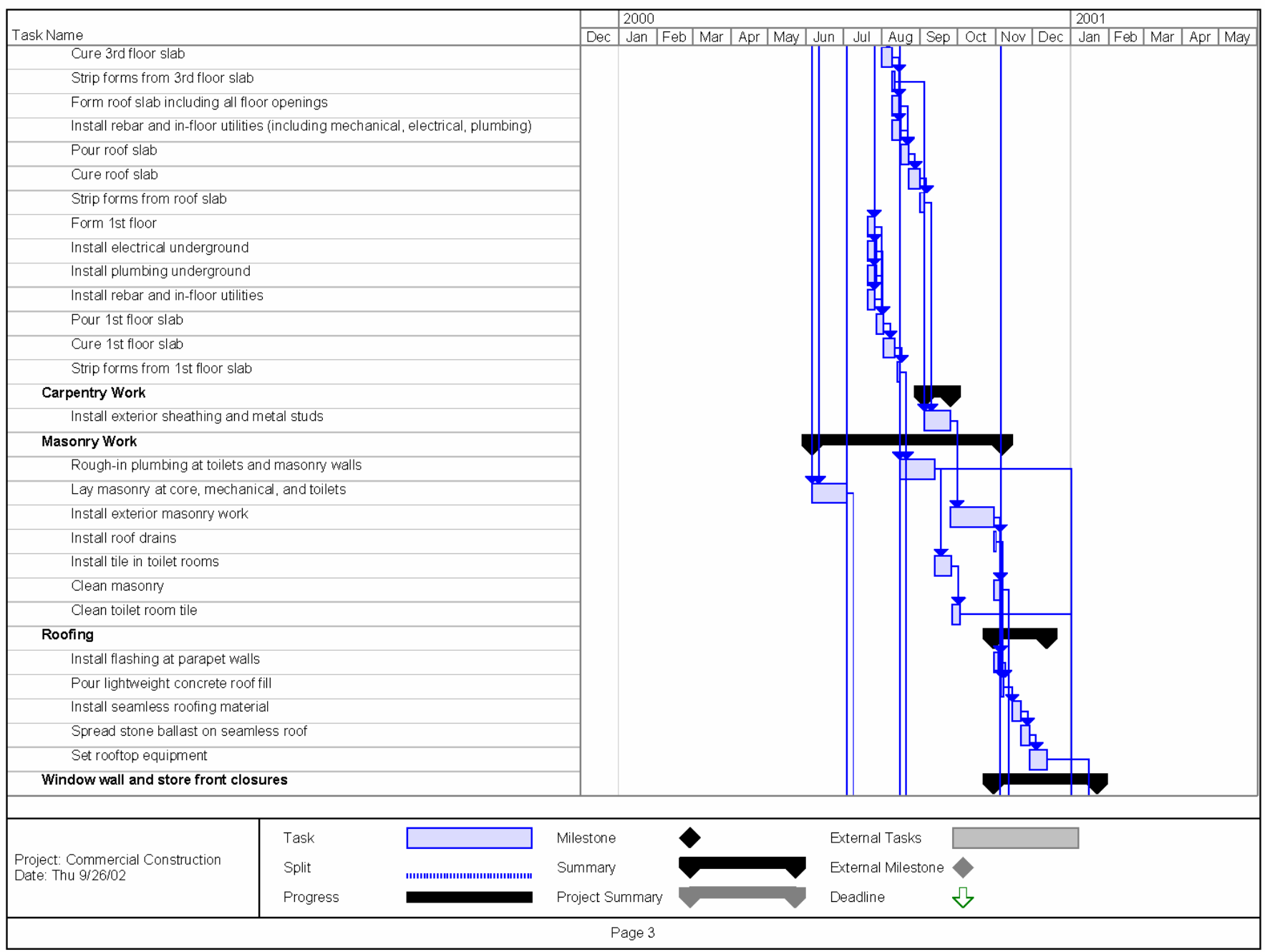

Figure C.1 Commercial Construction Steps, continued. 


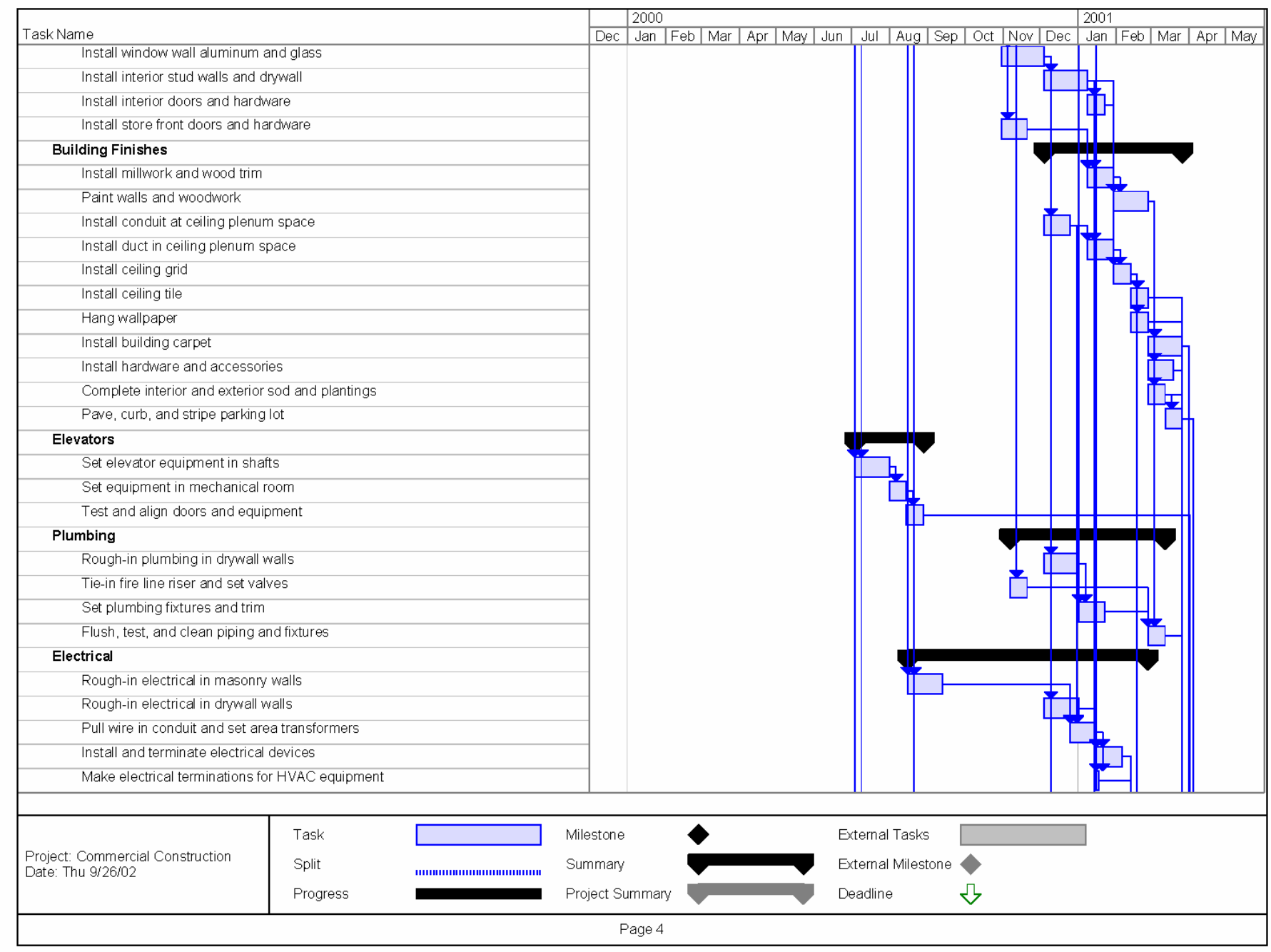

Figure C.1 Commercial Construction Steps, continued. 


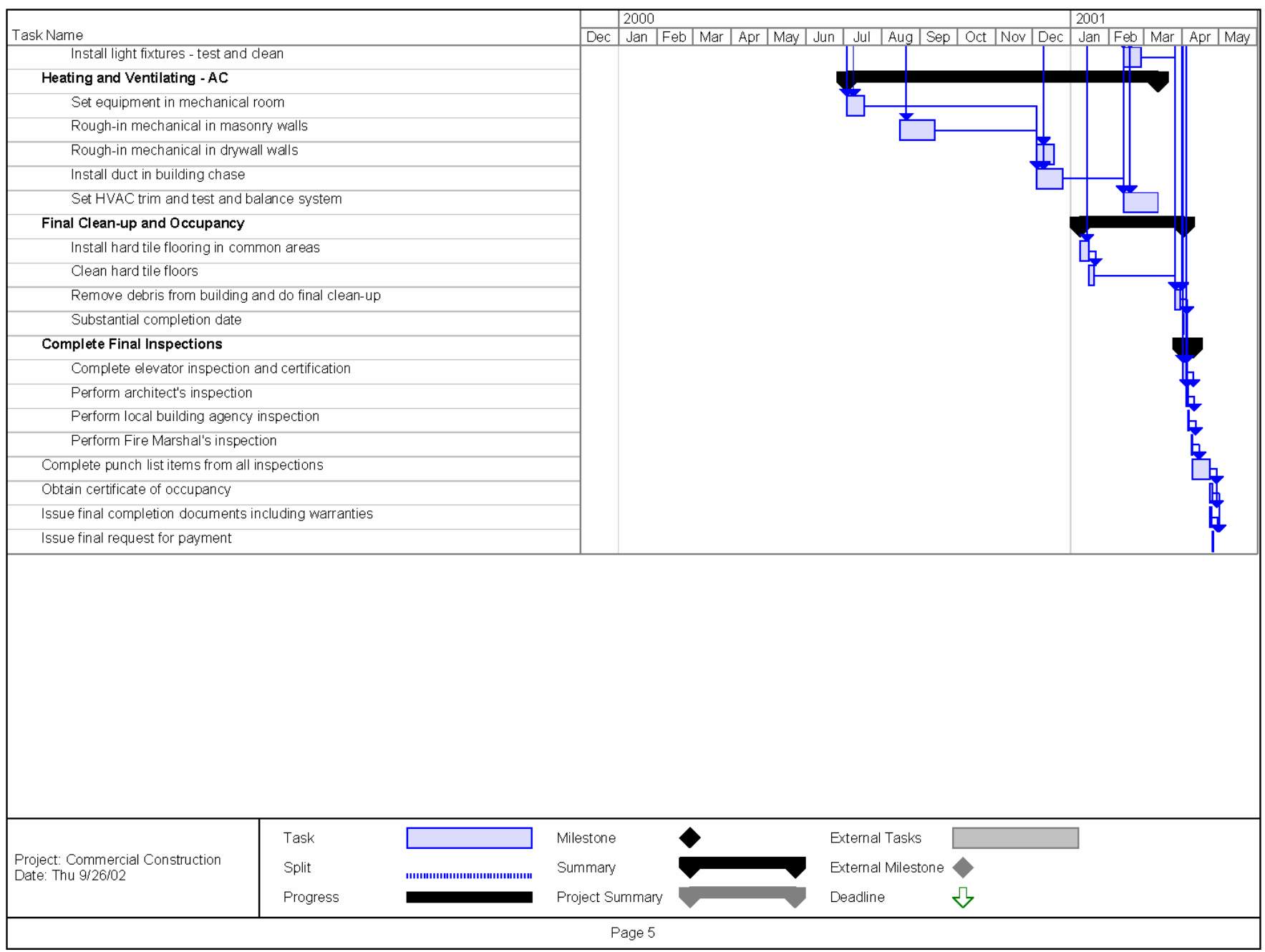

Figure C.1 Commercial Construction Steps, continued. 


\section{Appendix D: Critical Path Analysis Tool Documentation}

\section{D.1 Tool Description and System Requirements}

The Critical Path Analysis (CPA) Tool consists of several files in HyperText Markup Language (HTML) format, Microsoft ${ }^{\circledR}$ Word format and Adobe ${ }^{\circledR}$ Portable Document Format (PDF) that are linked together to present the information provided in the body of this report. The tool was

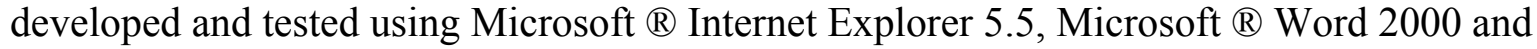
Adobe ${ }^{\circledR}$ Acrobat Reader 5.0. For best results the user should have these three programs installed and the file extensions .doc, .pdf and .htm registered in Windows so that the programs Word, Acrobat Reader, and Internet Explorer, respectively, are automatically launched when files with these extensions are opened.

\section{D.2 Tool Installation and Operation}

To install the tool using Windows Explorer, open (e.g., by double-clicking on the file name in Windows Explorer) the self-extracting Zip file CPA.exe. A WinZip "Self-Extractor" dialog box will be displayed requesting that a destination folder be specified for the unzip process. The user may change the default name of the destination folder by typing in the name of the desired folder in the text box. Within the dialog box, the "Unzip" button should then be clicked. The files will automatically be copied into the folder displayed in the text box. Once the user has received the message that the files have been copied, the user should close the dialog box.

To run the tool, browse to the destination folder and double-click on the file index.htm. The CPA Main Menu will appear as shown in Figure D.1. The following paragraphs describe the menu options.

\section{Critical Path View - By Building Technology}

Use this option to drill down to the information presented in Appendix A. Under this option, the user first selects the building technology (e.g., Roof, Insulation, Windows), then one of the critical path options (residential developments, residential custom construction, or commercial construction) to obtain a Gantt chart with one or more technology adoption decision points overlaid on the chart. Selecting a decision point will provide the user with information on the decision makers, decision influences, and sources of information. 


\title{
Critical Path View - By Decision Maker
}

Use this option to drill down to the information presented in Appendix A. Under this option, the user selects a building technology from a matrix of decision makers (contractor/subcontractor, owner/developer, and architect/designer) by critical path options (residential developments, residential custom construction, or commercial construction) to obtain a Gantt chart with one or more technology adoption decision points overlaid on the chart. Selecting a decision point will provide the user with information on the decision makers, decision influences, and sources of information.

\section{Critical Path Analysis Main Menu}

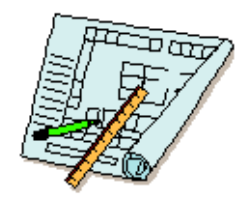

\author{
Critical Path View \\ - By Building Technology \\ - By Decision Maker
}

Documents

- Reports

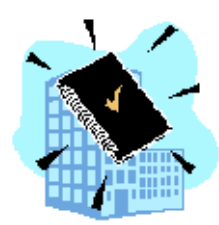

- Characterizing Building Construction Decision

Processes to Enhance DOE Program

Design (MSWord) (PDF)

- Tool Documentation (MSWord) (PDF)

- Gantt Charts

- Residential Construction

- Commercial Construction

\section{Background}

- About the Critical Path Tool

\section{Comments! Questions?}

Figure D.1 Critical Path Analysis Tool Main Menu

\section{Documents - Reports}

There are two items available from this option: the document Characterizing Building Construction Decision Processes to Enhance DOE Program Design and the Critical Path Analysis Tool Documentation (this appendix). Both documents are available in Microsoft ${ }^{\circledR}$ Word and PDF formats. 


\section{Documents - Gantt Charts}

This option provides access to the detailed Gantt charts developed in Microsoft ${ }^{\circledR}$ Project for the design and construction of a 3,000 square feet single-family house with full basement (residential construction) and a 76,000 square feet three-story office building (commercial construction). The Gantt charts are available in both Graphics Interchange Format (GIF) and PDF formats. 


\section{Distribution}

No. of

$\underline{\text { Copies }}$

\section{OFFSITE}

Jerry Dion (3)

U.S. Department of Energy

EERE-Office of Planning, Budget Formulation, and Analysis (EE-3B)

1000 Independence Avenue, S.W.

Washington, DC 20585

Michael McCabe

U.S. Department of Energy

EERE-Building Technologies

Program (EE-2J)

1000 Independence Ave., S.W.

Washington, DC 20585

John D. Ryan

U.S. Department of Energy

EERE-Building Technologies

Program (EE-2J)

1000 Independence Ave., S.W.

Washington, DC 20585

Qonnie Laughlin

U.S. Department of Energy

EERE-Building Technologies

Program (EE-2J)

1000 Independence Ave., S.W.

Washington, DC 20585

Dru Crawley

U.S. Department of Energy

EERE-Building Technologies

Program (EE-2J)

1000 Independence Ave., S.W.

Washington, DC 20585

Mark Bailey

U.S. Department of Energy

EERE-Weatherization and Intergovernmental

Program (EE-2K)

1000 Independence Avenue, S.W.

Washington, DC 20585
Mike Gonzalez

U.S. Department of Energy

EERE-Office of Planning, Budget Formulation, and Analysis (EE-3B)

1000 Independence Avenue, S.W.

Washington, DC 20585

David Hansen

U.S. Department of Energy

EERE-Building Technologies

Program (EE-2J)

1000 Independence Ave., S.W.

Washington, DC 20585

Ed Barbour

Navigant Consulting

1801 K Street, NW

Suite 500

Washington, D.C. 20006

No. of

Copies

ONSITE

2 DOE Richland Operations Office

Kim Williams

K8-50

28 Pacific Northwest National Laboratory

D. M. Anderson

K5-06

R. Bartlett

K5-02

D. B. Belzer

K5-06

K. A. Cort

K5-06

M. A. Crawford

K6-01

J. A. Dirks

K6-10

D. B. Elliott

Portland/1/OS

E. M. Fathelrahman K5-06

C. J. Hostick K8-23

D. J. Hostick K5-06

L. E. Larson K8-23

S. C. McDonald (5) BWO

A. K. Nicholls BWO

B. F. Saffell K5-02

L. J. Sealock K5-02

M. J. Scott K5-06

M. Skumanich Offsite/BSRC

A. L. Slavich Offsite/BSRC

T. M. Weber K6-01

Information Release Office (5) K1-06

Distr. 1 